\title{
Googling the present
}

Graeme Chamberlin

Office for National Statistics

\section{Summary}

Google Trends data provides weekly reports on the number of search queries made by people in a geographical area and by category. As over three quarters of those who access the Internet regularly are looking for information on goods and services - this information may be a useful indicator of economic activity. For example, the volume of queries may relate to future patterns of spending. This article investigates this use of Google Trends data for various search categories, looking at its correlation with official data on retail sales, property transactions, car registrations and foreign trips.

\section{Introduction}

The Office for National Statistics (ONS) conducts an annual survey to measure Internet access and individuals' use of the Internet across the UK. The 2010 results show that Internet usage continues to become more widespread among the adult population with the range of activities undertaken online also increasing.

Figure 1 shows that in 2010 there were 38.3 million Internet users in the UK, defined as those that had accessed the Internet in the three months prior to being interviewed for the survey. This represents 77 per cent of the UK adult population aged 16 and over. Of those, the number of adults accessing the Internet everyday has grown year on year to 30.1 million in 2010, 60 per cent of UK adults aged 16 or over. This is nearly double the level of 16.5 million (35 per cent of UK adults aged 16 and over) in 2006.

At the same time the proportion of adults who have never used the Internet continues to fall (Figure 2). In 2001 nearly half (48.5 per cent) of the UK adult population had never used the Internet. This fell to 35 per cent (16.7 million) by 2006 and then to 18 per cent ( 9.2 million) in 2010 . As Figure 2 also shows, those who have never used the Internet are concentrated in the older generations. In 2010, 60 per cent of adults aged over 65 had never used the Internet, making up nearly two-thirds (64 per cent) of the UK total, whilst only 1 per cent of those aged 16-24 had never used the Internet.

Frequency of use has grown hand in hand with the technology available to access the Internet. Now, almost all home access is via a broadband connection, compared to almost none about one decade ago when connections were via dial-up (Figure 3). The use of other forms of ICT has also 


\section{Figure $1 \quad$ Frequency of internet access}

United Kingdom

Millions of adults aged 16 or over

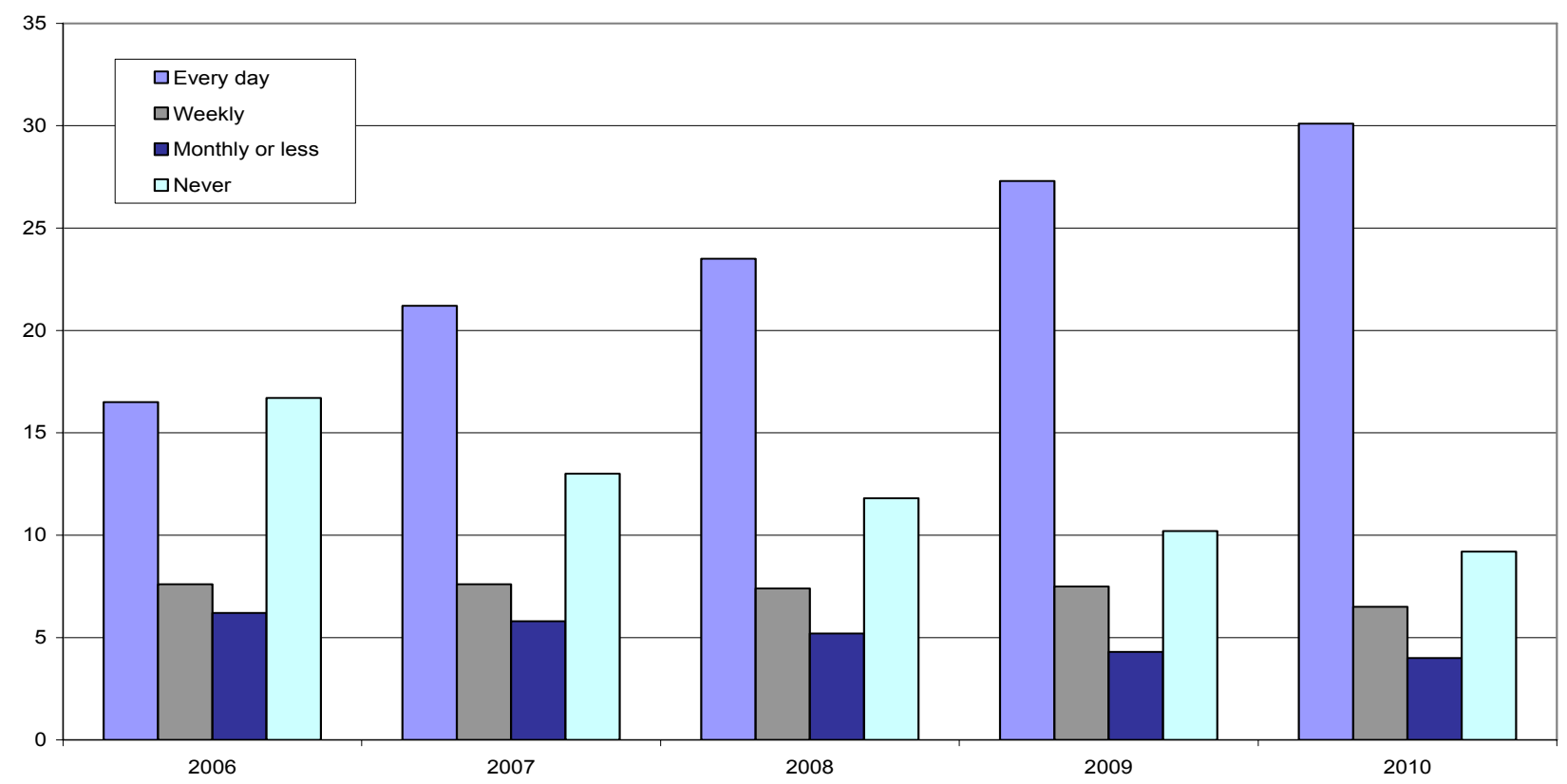

Source: Internet Access 2010

Figure 2 Adults who have never used the internet by age United Kingdom Per cent

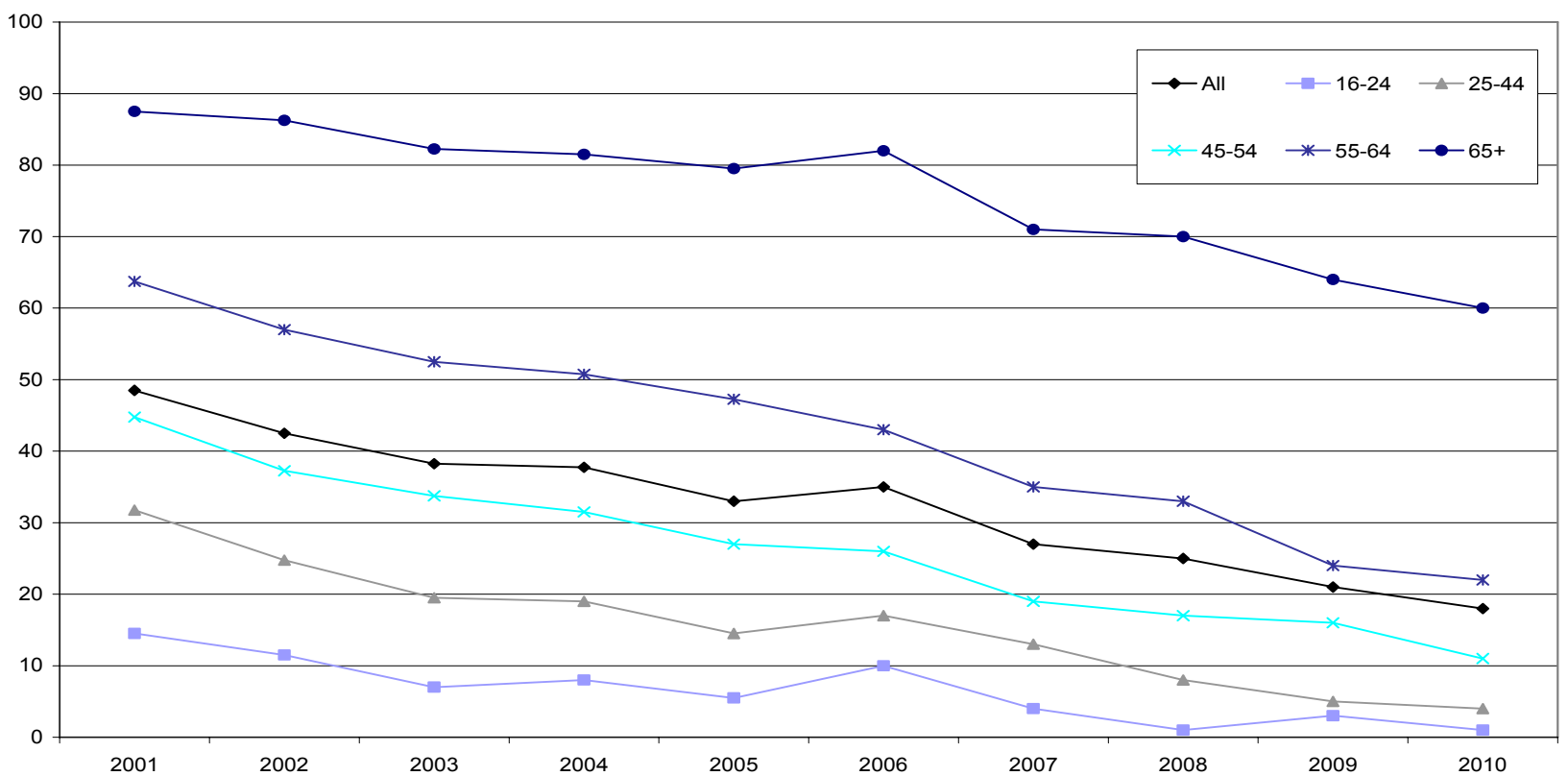

Source: Internet Access 2010 


\section{Figure $3 \quad$ Modes of accessing the Internet ${ }^{1}$}

United Kingdom

Per cent

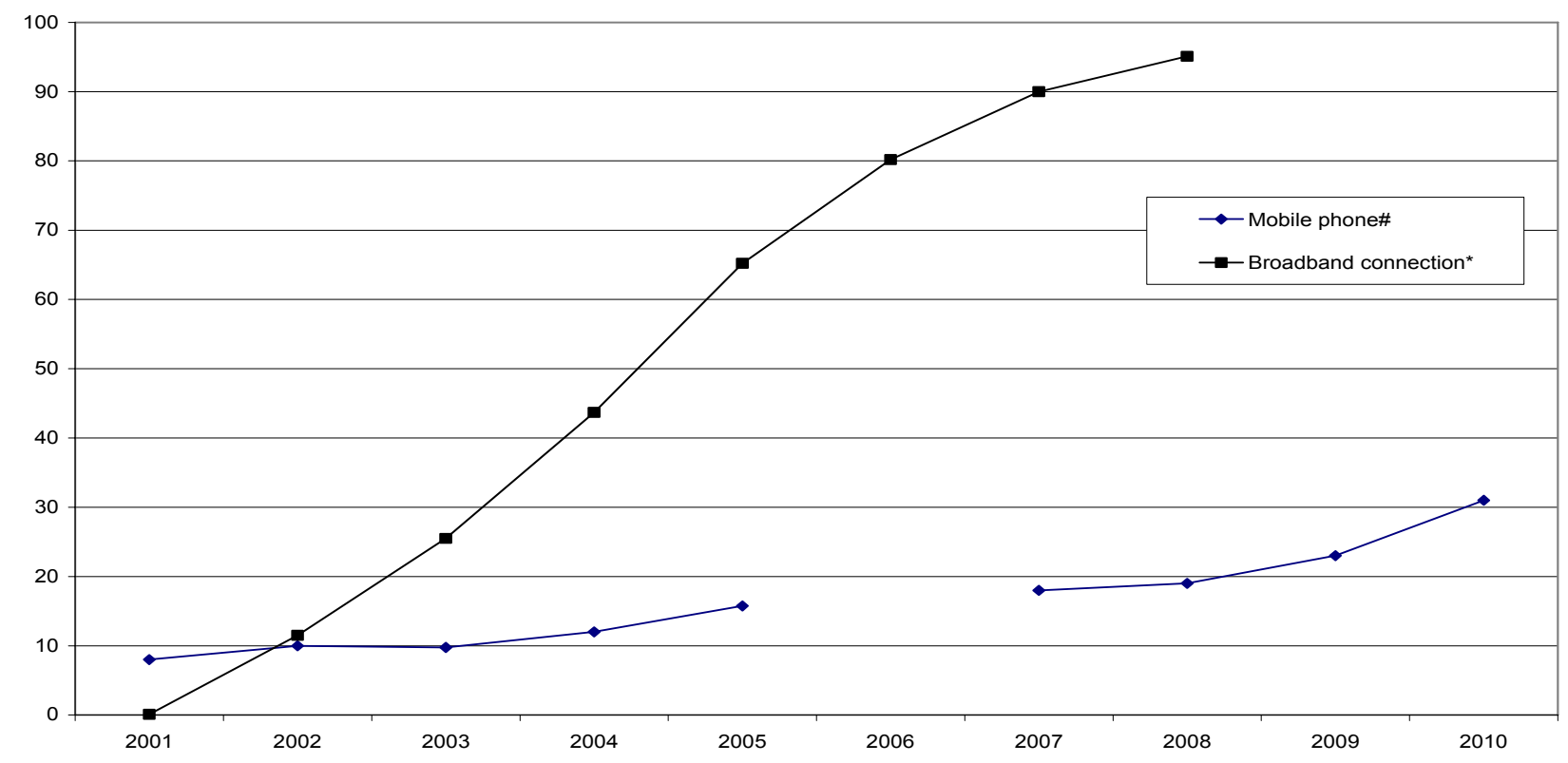

Notes

1. Per cent of those who accessed the Internet in the last three months

* As opposed to a dial-up connection

\# Data missing for 2006

Source: Internet Connectivity 2008 and Internet Access 2010

become more significant. Away from business or home, the mobile phone has become the most popular way to access the Internet wirelessly. In 2010, 31 per cent of those who accessed the Internet in the last three months did so with a mobile phone, up from 23 per cent a year earlier. This proportion was particularly high in the 16-24 age category, where 44 per cent of those who had accessed the Internet in the last three months had done so with a mobile phone. Wi fi hotspots in places such as cafes, hotels, railway stations and airports have continued to expand accounting for 2.7 million (7 per cent) of regular Internet users in 2010, up from 0.7 million in 2007.

Figure 4 shows the main types of activity undertaken online by individuals in the UK. A number of these have become more significant over time such as social networking and chat sites, Internet banking and online radio and television (on demand entertainment). The use of the Internet in these cases has undoubtedly been helped by improvements in technology allowing faster and more secure access. However, the main reasons for using the Internet have, as a proportion of total users, been relatively unchanged over the last decade. Email remains the most widespread activity undertaken, but finding information about goods and services and using the Internet for planning and making travel arrangements have also been ranked consistently high. In 2010 , almost 29 million adults who had accessed the Internet in the three months before the survey had 
used it to find information about goods and services and 24 million for using services related to travel and accommodation.

\section{Figure $4 \quad$ Internet activity ${ }^{1}$}

United Kingdom

Per cent

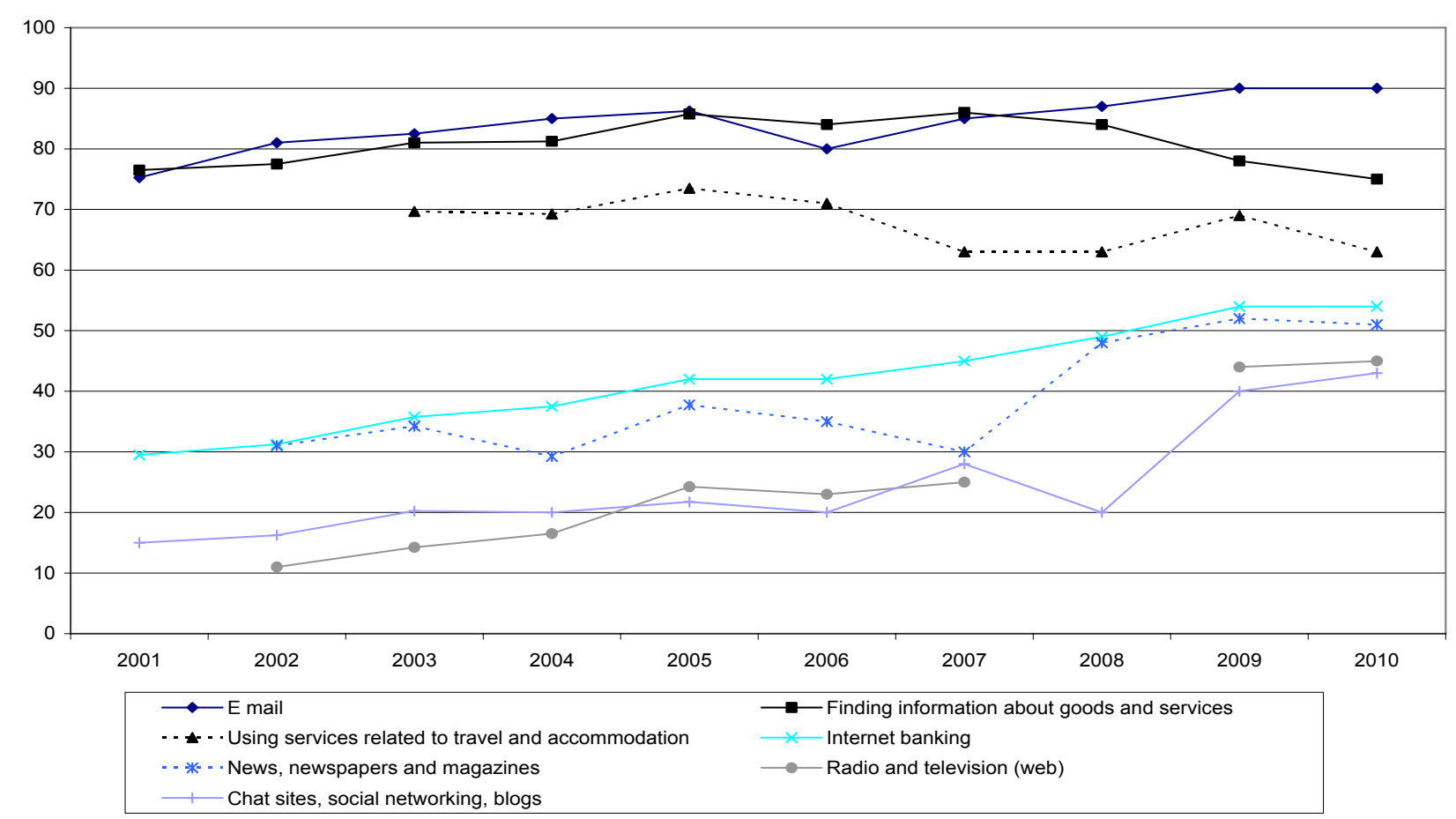

Notes

1. Percentage of those who accessed in the last three months

Source: Internet Access 2010

Actual purchases of goods and services over the Internet have also been on the increase.

According to the latest Internet Access survey, in 2010, 31 million UK adults bought or ordered goods and services online in the 12 months before the survey - this is 62 per cent of all UK adults. Figure $\mathbf{5}$ shows the distribution of these purchases across different categories of spending. Over half (52 per cent) of those who had purchased online in 2010 had bought clothes and sports goods. Films and music took second place (47 per cent), followed by holiday accommodation (44 per cent), household goods (44 per cent), books, magazines and newspapers (39 per cent) and other travel arrangements (36 per cent). The majority of those purchasing films and music and books, magazines and newspapers online did so by downloading or accessing directly from websites rather than delivered by post. The main reasons for purchasing over the Internet are convenience, easy to use websites, availability of goods and services not in the local area and lower prices (Figure 6). 


\section{Figure 5 Purchases over the Internet in $2010^{1}$}

United Kingdom

Per cent

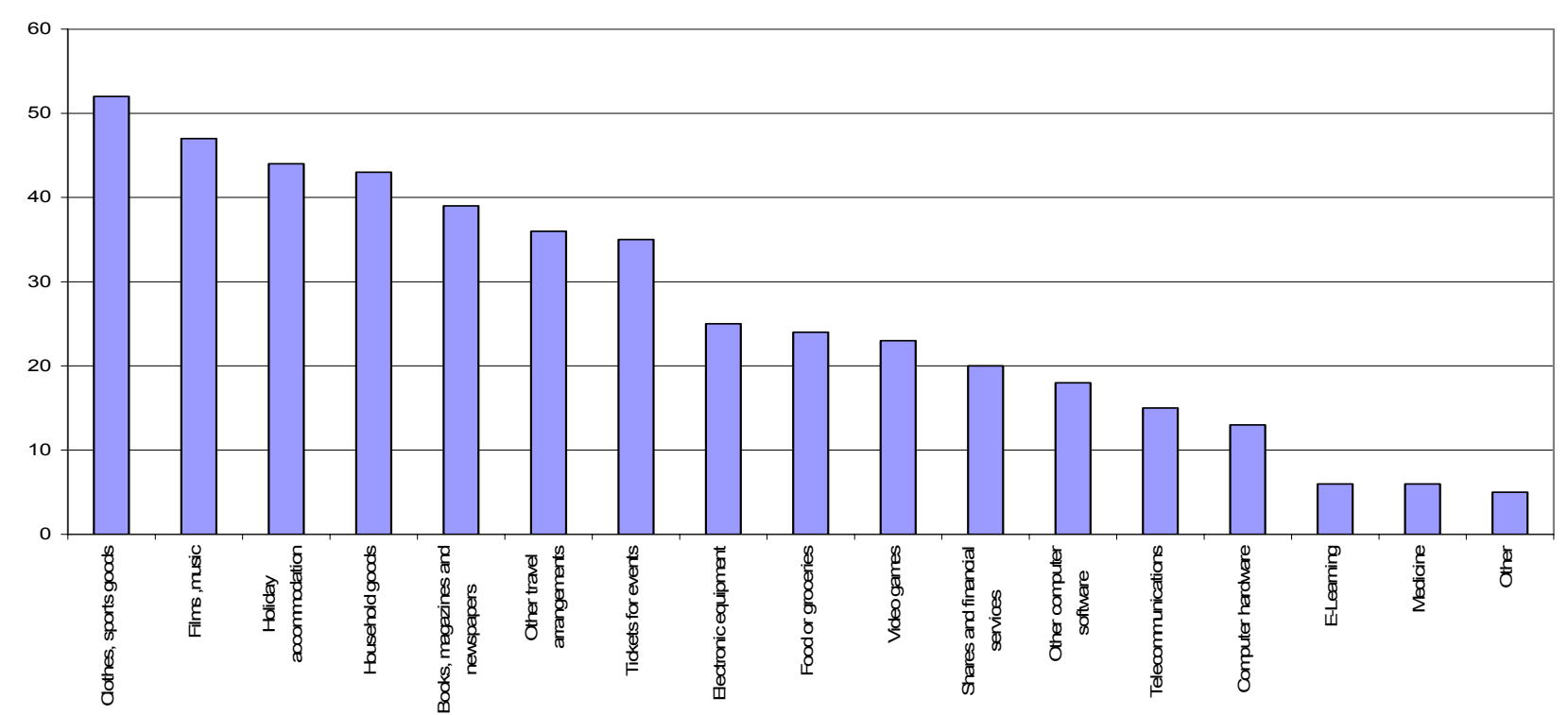

Note

1. Adults who had bought or ordered goods and services in the last 12 months

Source: Internet Access 2010

Figure $6 \quad$ Reasons for ${ }^{1}$ and for not $^{2}$ purchasing over the Internet United Kingdom

Per cent

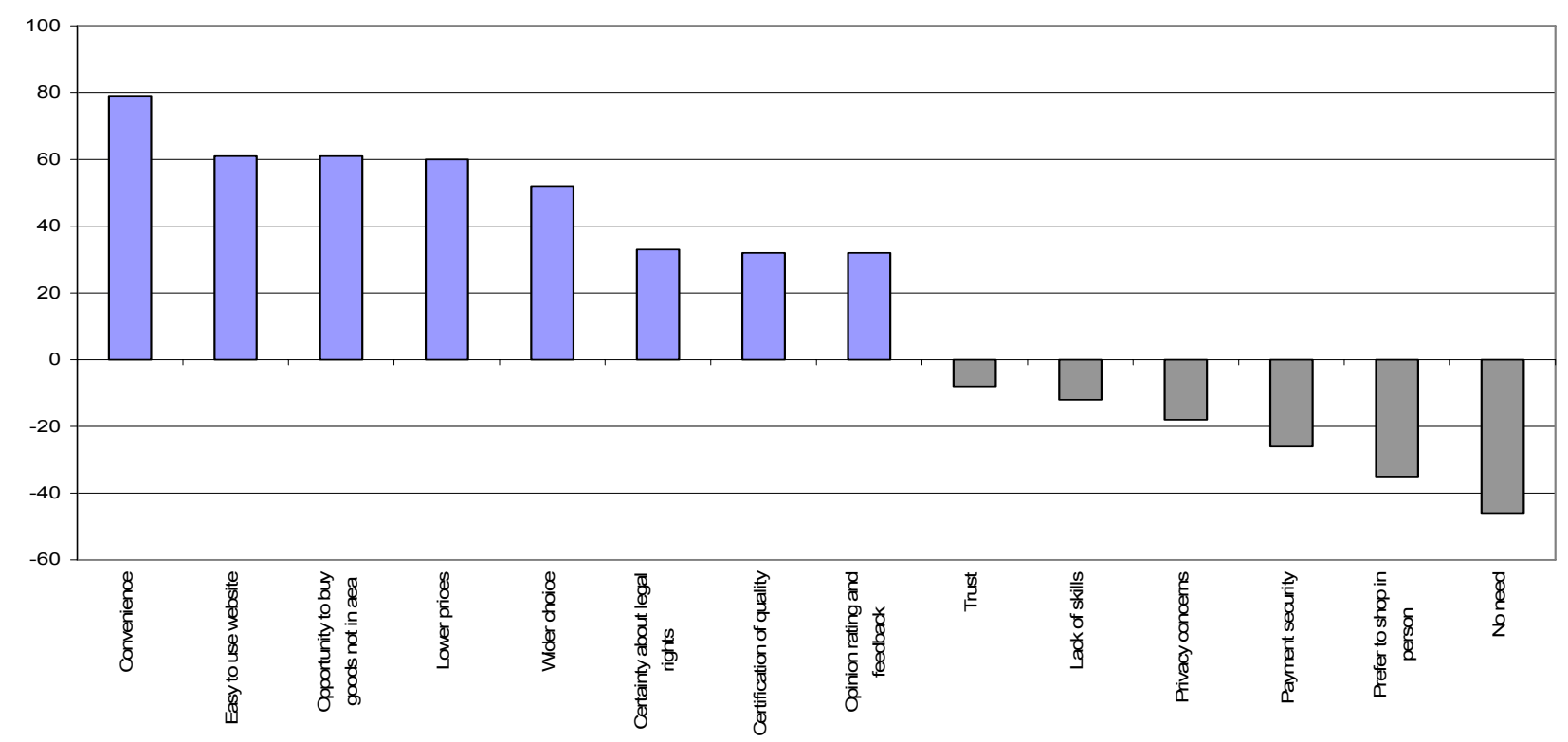

1. Shown in blue and based on adults who had bought online in the last 12 months

2. Shown in the grey bars as negative percentages - based on those who had not bought online in the previous 12 months (including never).

Source: Internet Access 2009 
These trends have been reflected in official measures of retail sales where the proportions of online sales are now reported separately (see McLaren 2010 for the latest methodology). In October 2010, average weekly Internet sales were $£ 543.1$ million - constituting 9.6 per cent of total weekly retail sales of $£ 5.69$ billion. This proportion has risen steadily since the start of the time series in 2006 (see Figure 7, note that the figures reported here are not seasonally adjusted).

\section{Figure $7 \quad$ Internet retail sales}

\section{Great Britain}

Per cent of total retail sales, Not seasonally adjusted

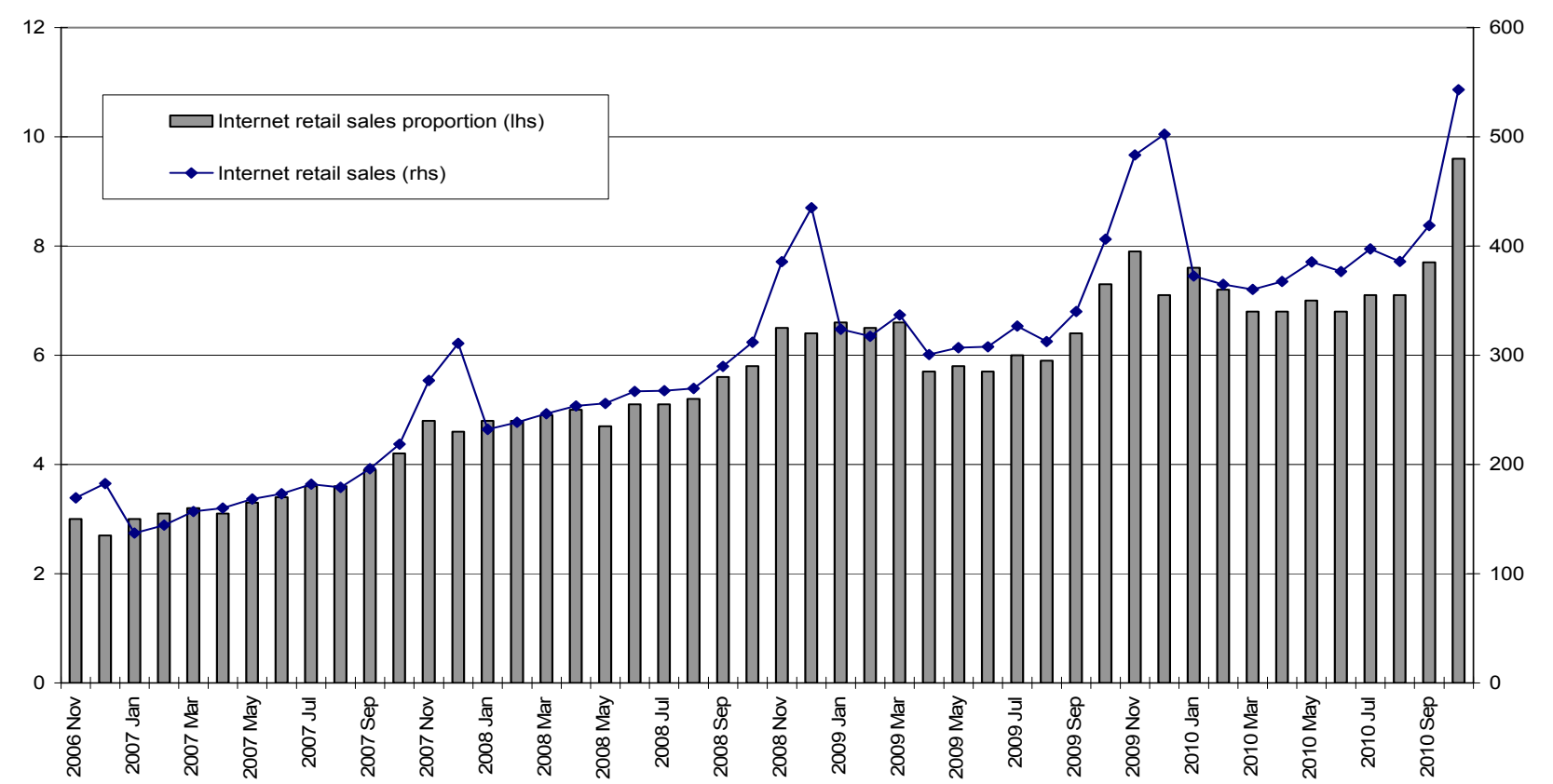

Source: Retail sales October 2010

ONS also runs an annual E-Commerce survey reporting on business use of Information and Communication Technologies (ICT) in the UK. The number of businesses with a website has increased year on year to 76.0 per cent in 2009, up from 66.9 per cent in 2004 (Figure 8). In 2009 almost all large businesses, defined in terms of numbers of employees, had a website. The proportion of smaller businesses with a website has increased between 2004 and 2009 but is still lower than for larger businesses.

The E-Commerce survey also reports on the percentage of businesses that make sales over websites. Figure 9 shows the proportion of businesses making sales over a website by size (in terms of employment) and by industry in 2009. In line with the data on businesses with a website, larger businesses are more likely to make sales over a website than smaller businesses. 37.8 per cent of businesses with over 1000 employees made sales over a website compared to 13.2 per cent of those with 10-49 employees. Businesses in the utilities, wholesale, retail, transport and information and communications industries were more likely to make sales over a website. 


\section{Figure $8 \quad$ Businesses ${ }^{1}$ with a website}

United Kingdom

Per cent

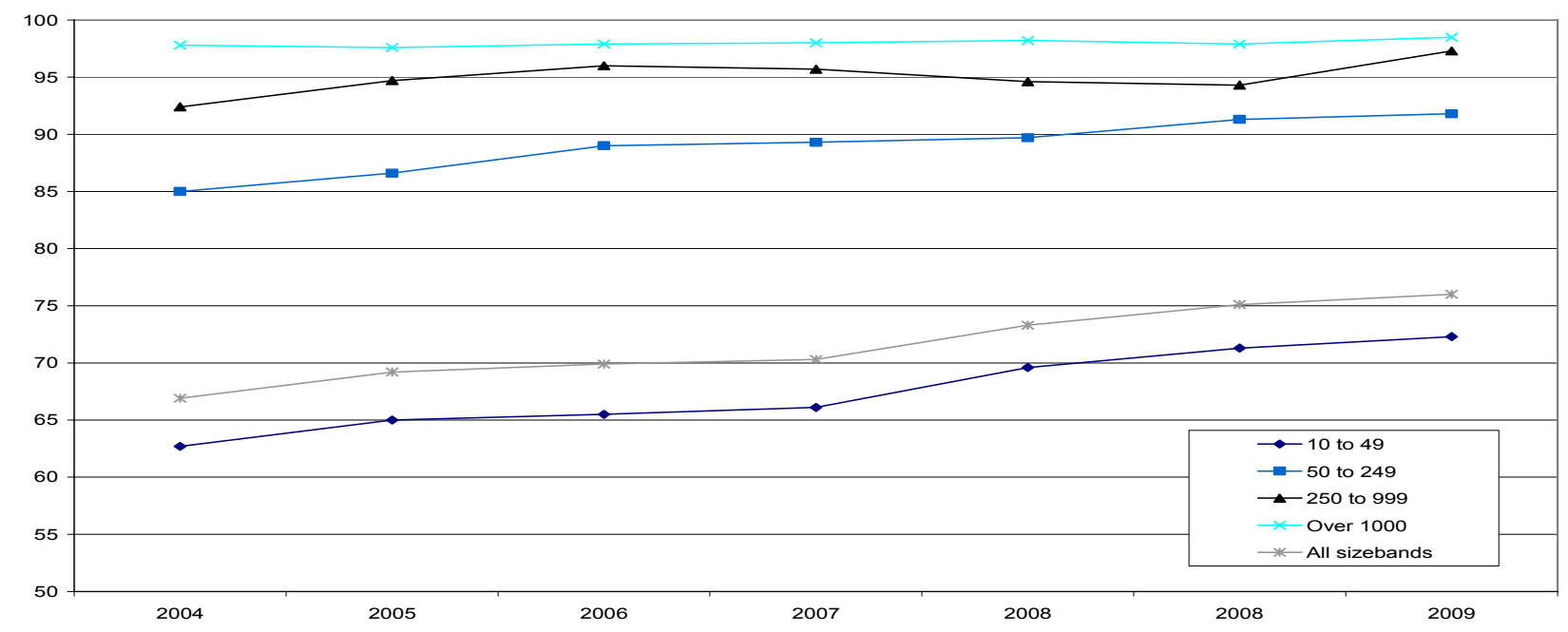

Note

1. Businesses are shown by size in terms of employment

Source: E-Commerce survey 2009

\section{Figure 9 Sales over a website by size ${ }^{1}$ and industry ${ }^{2}, 2009$}

United Kingdom

Percentage of firms making sales over a website

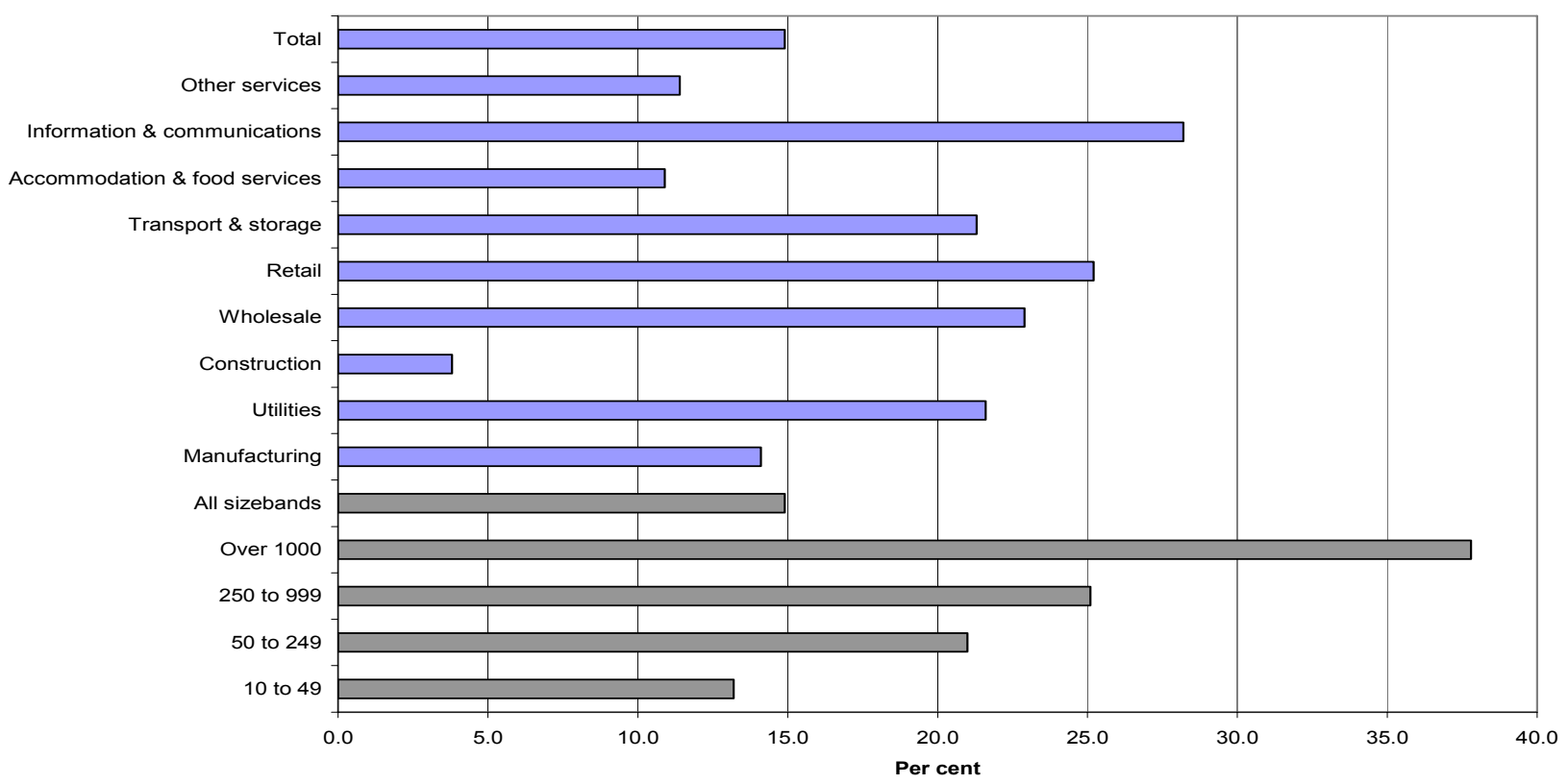

Source: E-Commerce Survey 2009

Notes

1. Size is shown by employment bands in the grey bars

2. Industry is shown in the blue bars 
Evidence from household and business surveys clearly show the high and growing importance of the Internet for communication and finding out information. The main focus of this article is to investigate whether the use of the Internet for information gathering bears any relationship to actual activity in the UK. For example, do Internet searches for types of products or vendors relate to actual retail sales? Other examples considered in this article include car registrations, property transactions and trips overseas and whether Internet searches show any correlation with actual activity. The next section outlines the source of this Internet search information before its correlation with various economic time series is assessed.

\section{Google Trends}

Search engines, such as Google (www.google.com), are widely used by people to navigate their way around the World Wide Web. By collecting data on the search queries made by people, Google Trends provides indices of the volume of Google queries by geographic location and category. This offers a potentially interesting resource for analysing people's intentions - including their expenditure decisions. (see www.google.com/insights/search).

Choi and Varian (2009), two economists affiliated to Google, examined the usefulness of Google Trends data for predicting various types of spending. Their argument is, because Google Trends data are practically available in real time, any statistical relationship between actual sales and Google Trends can be exploited to produce more timely estimates of data. For example, official retail sales data are only available with a lag of several weeks, whereas a model based on Google Trends data could produce estimates much faster. This approach to producing more rapid estimates of present data is commonly referred to as nowcasting, as the idea is to predict the present rather than the future (forecasting).

This article replicates some of this original study, which was applied to the US, to various aspects of UK data. It stops short of producing nowcasts, but investigates whether there is any association between various categories of searches and activity in retail sales, car registrations, property sales and financing, and overseas visits. Any such relationship is predicated by the widespread use of the Internet by individuals and businesses described in the previous section.

Google Trends data are presented in the form of a query index rather than the raw number of searches for a particular category or item. This is based on the query share, which is the number of searches for that particular category or item in a given geographic region at a point in time as a share of the total number of queries. This is then normalised so that they start at zero on 1 January 2004 , with the index at subsequent dates showing the percentage change in the query share relative to 1 January 2004.

An approach based on query share therefore needs to be interpreted carefully. For example, a falling query share over time is not necessarily an indicator that the raw number of searches are also falling over time. In fact, due to the large rise in total searches in recent years as Internet use becomes more frequent and widespread, a falling query share might just reflect lower than average growth. Particular examples of where this is likely to be the case are categories consisting of a high 
proportion of early Internet users such as travel websites (lastminute.com) and computer retailers/wholesalers (Dell). In 2004 these are likely to have had a relatively high share of total Internet searches, but over time as more businesses start using the Internet, this share will naturally fall.

Choi and Varian (2009) test the significance of Google Trends data by seeing if it offers a statistical improvement over a basic seasonal autoregressive model. That is, the following regression is run on monthly data:

$$
y_{t}=\beta_{0}+\beta_{1} y_{t-1}+\beta_{2} y_{t-12}+\beta_{3} x_{t}
$$

where

$y$ is the variable of interest and $x$ is a relevant category (or categories) of Google Trends data. If the coefficient $\beta_{3}$ is statistically significant, then it suggests that Google Trends data improves the fit of the model. Their motivation is to assess the nowcasting potential of Google Trends data. Given its relative timeliness it can enter the above regression contemporaneously and then be used to form estimates of $y$ before it is officially published.

This article estimates similar models for various categories of spending and activity in the UK. However, given the earlier point of trends in query shares it arguably makes more sense to estimate the model in first differences (that is monthly changes rather than levels).

$$
\Delta y_{t}=\beta_{0}+\beta_{1} \Delta y_{t-1}+\beta_{2} \Delta y_{t-12}+\beta_{3} \Delta x_{t}
$$

This removes the issue of longer term trends from the analysis, essentially narrowing the focus on Google Trend's ability to predict short-term movements in the variable of interest. Estimating the model in first differences also makes sense from the econometric perspective as the normal way of dealing with non-stationary data. Otherwise, trends in the time series may lead to a spurious finding of significance.

Finding a significant $\beta_{3}$ coefficient implies that using Google Trends data offers an improvement over a simple (naïve) backward-looking time series model and suggests that it may be a useful indicator for nowcasting. Of course, a better test of nowcasting potential is to test the significance of Google Trends data out of sample and, where relevant, on real time data. This is not investigated in this article but is something that could be explored by interested readers.

However, it should also be noted that if the coefficient $\beta_{3}$ is found to be insignificant it does not necessarily imply that Google Trends data is without use. For example, if the variable of interest has behaved in a very orderly way then past lags of the data may have high statistical significance (predictive ability) reducing the scope of Google Trends data to improve the model fit. That does not imply that the Google Trends data itself is not an interesting and timely indicator of certain activity.

Google classifies search queries into 27 categories at the top level and 241 categories at the second level using an automated classification engine. Queries are assigned to particular categories using natural processing methods. For example, the query 'Car tyre' would be assigned 
to the category 'Vehicle tyres' which is a subcategory of 'Auto parts' which in turn is a subcategory of 'Automotive'. Table 1 shows a number of official data sources and potentially relevant Google search categories. The top searches and rising searches in each category are shown in the Appendix. Many of the official data sources are drawn from ONS retail sales, and given the evidence from the E-Commerce survey, time series relating to large businesses are used where available.

\section{Table $1 \quad$ Official data and relevant Google Trends categories}

\begin{tabular}{|c|c|c|}
\hline Official data & Source & Relevant Google Trends categories \\
\hline All retailing (large firms) & ONS Retail Sales & 'Shopping' \\
\hline $\begin{array}{l}\text { Non-specialised food stores } \\
\text { (large firms) }\end{array}$ & ONS Retail Sales & 'Food retailers' \\
\hline $\begin{array}{l}\text { Non-specialised non-food } \\
\text { stores }\end{array}$ & ONS Retail Sales & 'Mass merchants and department stores' \\
\hline $\begin{array}{l}\text { Textiles, clothing and footwear } \\
\text { (large firms) }\end{array}$ & ONS Retail Sales & 'Apparel', 'Clothing retailers' and 'Clothing labels and designers' \\
\hline Furniture and lighting & ONS Retail Sales & 'Lighting', 'Home and garden', 'Home making' and 'Home furnishings' \\
\hline Home appliances & ONS Retail Sales & 'Electrical household appliances' \\
\hline Hardware, paints and glass & ONS Retail Sales & 'Home improvement' \\
\hline $\begin{array}{l}\text { Audio video equipment and } \\
\text { recordings }\end{array}$ & ONS Retail Sales & $\begin{array}{l}\text { 'Music streams and downloads', 'Music retailers', 'Audio equipment', } \\
\text { 'Consumer electronics' and 'Home video' }\end{array}$ \\
\hline $\begin{array}{l}\text { Books, newspapers and } \\
\text { stationery }\end{array}$ & ONS Retail Sales & 'Book retailers' \\
\hline $\begin{array}{l}\text { Computers and } \\
\text { telecommunications }\end{array}$ & ONS Retail Sales & $\begin{array}{l}\text { 'Personal electronics', 'Consumer electronics', 'Mobile and wireless', } \\
\text { 'Mobile phones' and 'Telecommunications' }\end{array}$ \\
\hline Non-store retailing (large firms) & ONS Retail Sales & 'Shopping portals and search engines' \\
\hline Car registrations & $\begin{array}{l}\text { Driver and Vehicle Licensing } \\
\text { Agency (DVLA) }\end{array}$ & $\begin{array}{l}\text { 'Vehicle licensing and registration', 'Automotive', 'Vehicle shopping', } \\
\text { 'Vehicle brands' and 'Auto financing' }\end{array}$ \\
\hline Property transactions (number) & Land Registry & 'Real estate' and 'Home inspections and appraisals' \\
\hline Mortgage approvals (number) & $\begin{array}{l}\text { Bank of England Financial } \\
\text { Statistics }\end{array}$ & 'Home financing' \\
\hline Overseas visits (number) & ONS Travel and Tourism & $\begin{array}{l}\text { 'Travel', 'Vacation destinations', 'Hotels and accommodation', 'Air travel' } \\
\text { and 'Cruises and charters' }\end{array}$ \\
\hline
\end{tabular}

\section{Results}

This section presents the results from estimating the simple time series model outlined in the previous section (based on first differences using monthly non-seasonally adjusted data) for each of the official data sources and potentially relevant Google Trends data listed in Table 1. Google Trends data is published weekly whereas official data is published monthly - therefore following Choi and Varian (2009) - Google Trends data relating to the second week of the month are used. 


\section{All retailing excluding fuel (large firms)}

Figure 10 shows the time series of this measure of retail sales and the Google Trends category 'Shopping'. Whilst there appears to be a good correlation between the short-term movements in the data, with both showing the same strong seasonal variation, the regression results find the Google Trends data to be insignificant. There are two possible reasons for this.

\section{Figure 10 Retail sales and Shopping}

Retail Sales Index

Google Trends query share

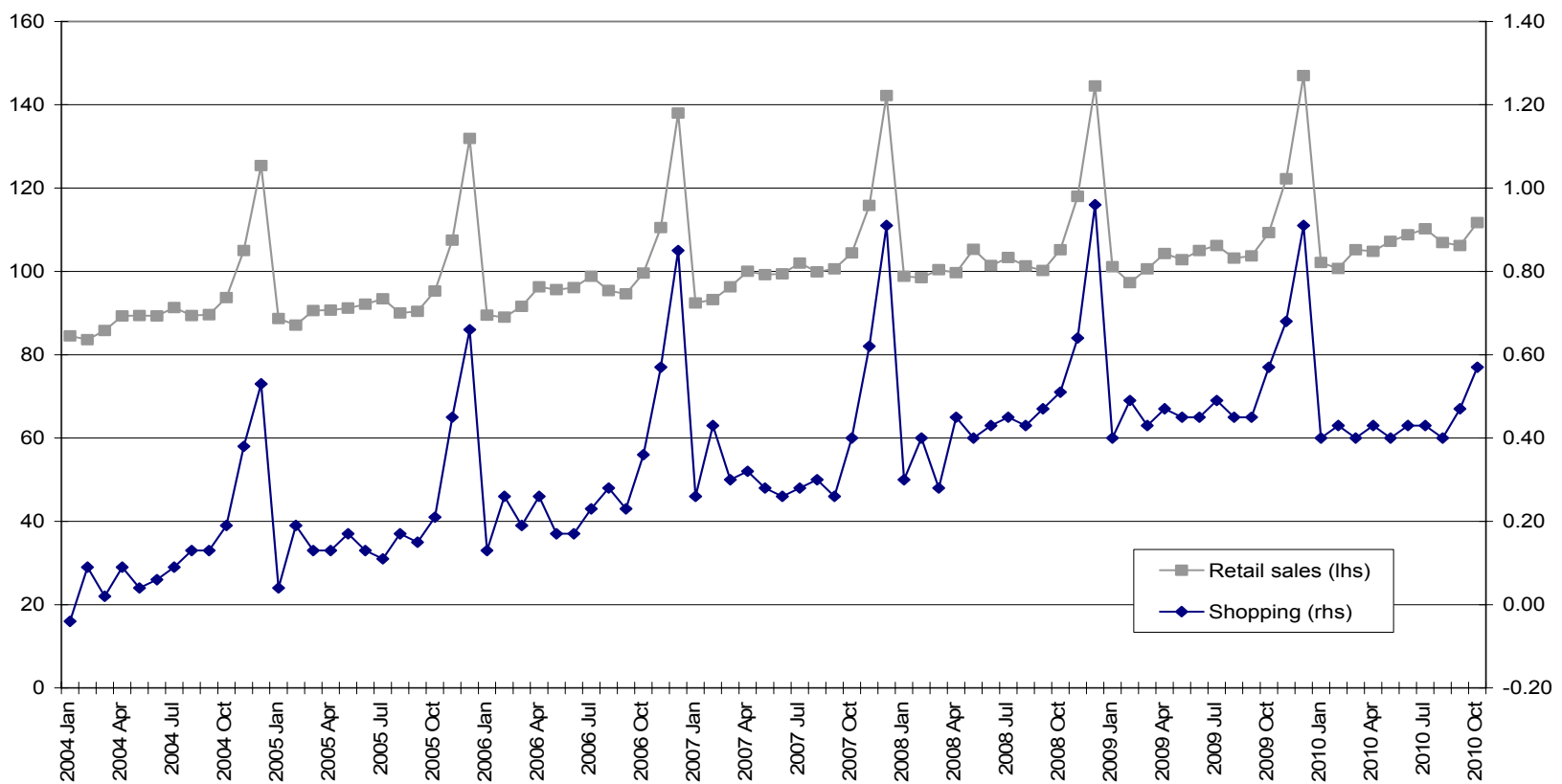

Source: ONS Retail Sales and Google Trends

\section{Dependent Variable: All retail sales excluding automotive fuel (large firms)}

Sample: 2004M02 2010M10

\begin{tabular}{lllll} 
& Coefficient & Std. Error & t-Statistic & Prob. \\
Constant & -0.000678 & 0.002445 & -0.277092 & 0.7825 \\
All retail sales excluding automotive fuel (large firms) (-1) & $-8.34 \mathrm{E}-05$ & 0.023321 & -0.003575 & 0.9972 \\
All retail sales excluding automotive fuel (large firms) (-12) & 0.937521 & 0.059707 & 15.70194 & 0.0000 \\
Shopping & 0.032843 & 0.041838 & 0.785013 & 0.4349 \\
\hline
\end{tabular}

First, the seasonal movements in the retail sales data may be adequately captured by the past history of the data, leaving little explanative room for the Google Trends data. This can be seen in the regression results where the twelfth lag of the retail sales data is highly significant pointing to a fairly regular seasonal pattern. Second, the makeup of the Google Trends 'Shopping' time series might not necessarily be a good indicator. 
The Appendix shows the top searches in each category. The top search itself is normalised to 100 with the volume of other searches presented relative to this. It can be seen that eBay is by far the top search and is the UK's largest online marketplace. But as Wallis (2006) notes, whilst this auction site may be an important element of online shopping, it does not constitute retail sales in the official sense - which are defined as goods sold by retailers. Some goods are sold directly by businesses on eBay, for example IBM has sold new products and offered services in both competitive auctions and at fixed (buy it now) prices. However, the majority of goods sold are transfers between households/consumers. eBay is a service that facilitates this transfer but is not a retailer so will not form part of the Retail Sales Index. As these transfers do not generate final demand or value-added they are also not included in household expenditure and gross domestic product. Here, only the fees and commissions paid for facilitating the sales and purchases of goods and services would count as final demand. Therefore, the 'Shopping' category may not fully correspond to total retail sales. Comparing Google Trends data with specific components of retail sales though may provide more significant results.

\section{Non-specialised food stores (large firms)}

This category of (predominantly food) retail sales mainly consists of supermarkets. As Figure 11 shows there is a high correlation with the Google Trends category of 'Food retailers', and the regression results find this to be significant. Top searches making up the 'Food retailers' category consist of Tesco (and Tesco Direct), ASDA (and George), Morrisons, Sainsburys, Aldi, Lidl, Ocado and Waitrose - all of the largest UK supermarket chains.

\section{Figure 11 Non-specialised food stores and Food retailers}

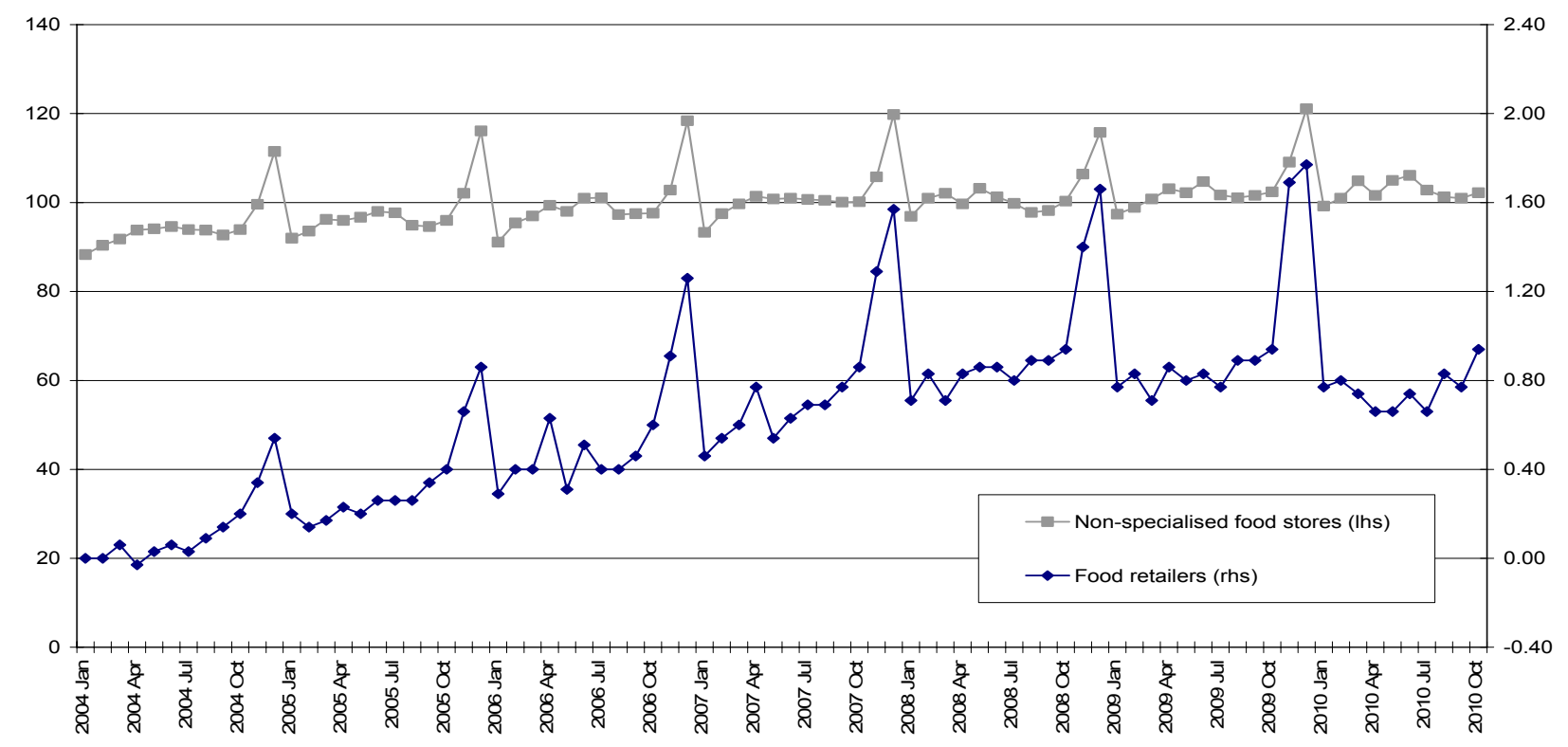

Source: ONS Retail Sales and Google Trends 


\section{Dependent Variable: Non-specialised food stores (large firms)}

Sample: 2004M02 2010M10

$\begin{array}{lllll} & \text { Coefficient } & \text { Std. Error } & \text { t-Statistic } & \text { Prob. } \\ \text { Constant } & -0.000643 & 0.002210 & -0.291082 & 0.7718 \\ \text { Non-specialised food stores (large firms) (-1) } & -0.036416 & 0.032208 & -1.130656 & 0.2617 \\ \text { Non-specialised food stores (large firms) (-12) } & 0.828919 & 0.058382 & 14.19827 & 0.0000 \\ \text { Food retailers } & 0.037285 & 0.015265 & 2.442520 & 0.0169\end{array}$

It can be seen that Figure 11 also shows the query share of the 'Food retailers' category in total queries to be generally growing over time. This may be partly attributed to the growing online presence of the UK's largest supermarket chains. Rising searches in this category, showing the fastest growing search queries, include ASDA Direct, Tesco Direct, ASDA online and Ocado (Waitrose/John Lewis Partnership).

\section{Non-specialised non-food stores (large firms)}

Large firms in this component of (predominantly non-food) retail sales are department stores and therefore map well to the Google Trends category of 'Mass merchants and department stores' where the top search queries include Marks and Spencer (various spellings and abbreviations), John Lewis, Debenhams, Next and River Island. Figure 12 shows a strong correlation between these two time series and the Google Trends data is found to be significant in the regression model.

\section{Figure 12 Non-specialised non-food stores and Mass merchants}

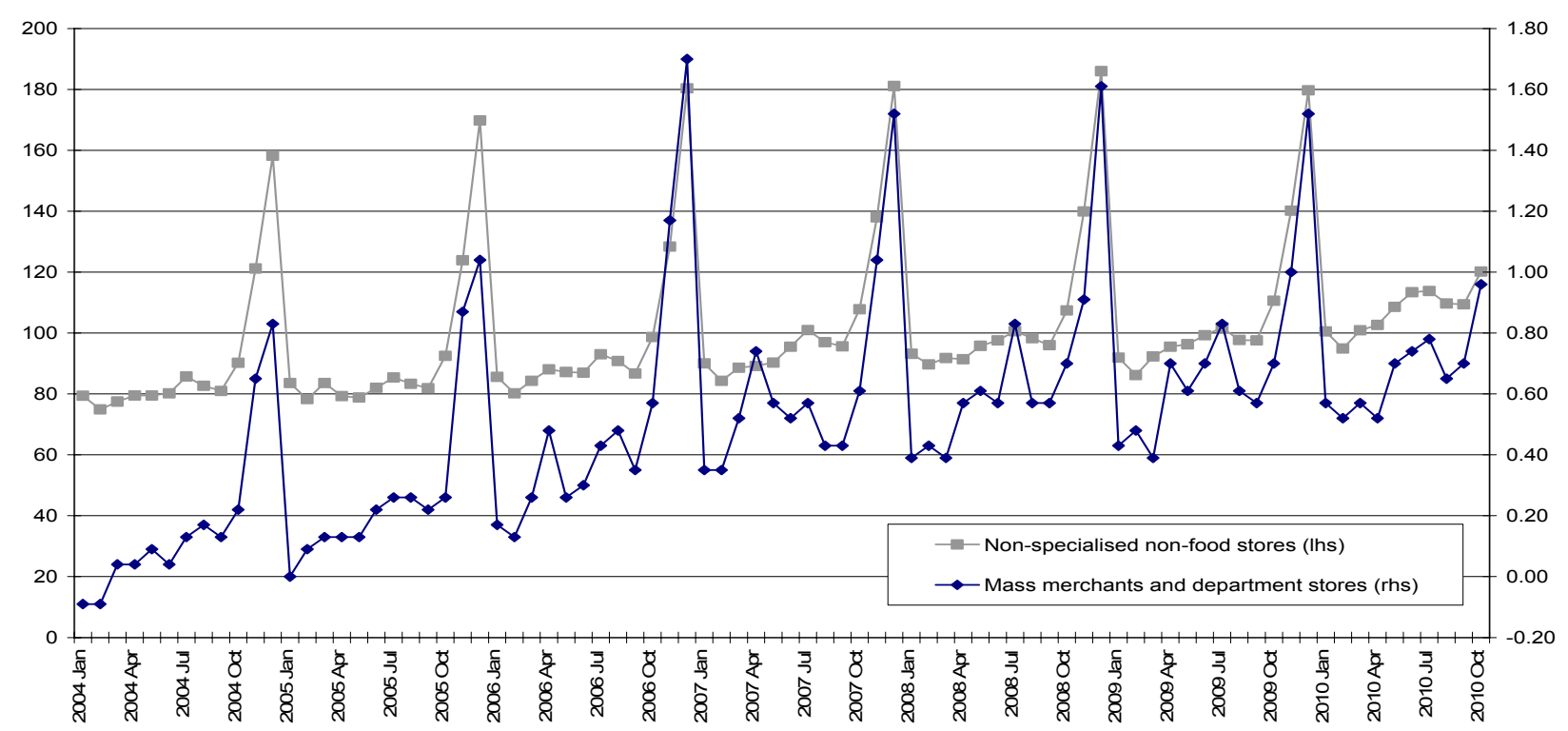

Source: ONS Retail Sales and Google Trends 
Dependent Variable: Non-specialised non-food stores

Sample: 2004M02 2010M10

$\begin{array}{lllll} & \text { Coefficient } & \text { Std. Error } & \text { t-Statistic } & \text { Prob. } \\ \text { Constant } & -3.01 \mathrm{E}-05 & 0.003453 & -0.008730 & 0.9931 \\ \text { Non-specialised non-food stores (-1) } & 0.005328 & 0.015621 & 0.341071 & 0.7340 \\ \text { Non-specialised non-food stores (-12) } & 0.845518 & 0.044809 & 18.86949 & 0.0000 \\ \text { Mass merchants and department stores } & 0.078724 & 0.027889 & 2.822718 & 0.0061\end{array}$

\section{Textiles, clothing and footwear (large firms)}

There are a number of Google Trends categories that may be good indicators of clothing and footwear retail sales (other textiles are relatively small). As it happens, 'Apparel' is the most significant in terms of regression results, and as shown in Figure 13, it moves broadly in line with the official retail sales data. 'Apparel' consists of top search queries for items such as shoes, boots, dress and clothes, with most of the rising searches corresponding to retailers such as New Look, River Island, Dorothy Perkins, Monsoon, Topshop, Debenhams and Next. Other relevant Google Trends categories were found to be insignificant. 'Clothing retailers' primarily consists of search queries for outlet centres like Bicester Village, McAthur Glen, Ashford outlet and outlet Swindon. 'Clothing labels and designers' mainly consist of clothing brands and this too was found to be an insignificant variable.

\section{Figure 13 Textiles, clothing and footwear and Apparel}

Retail Sales Index

Google Trends query share

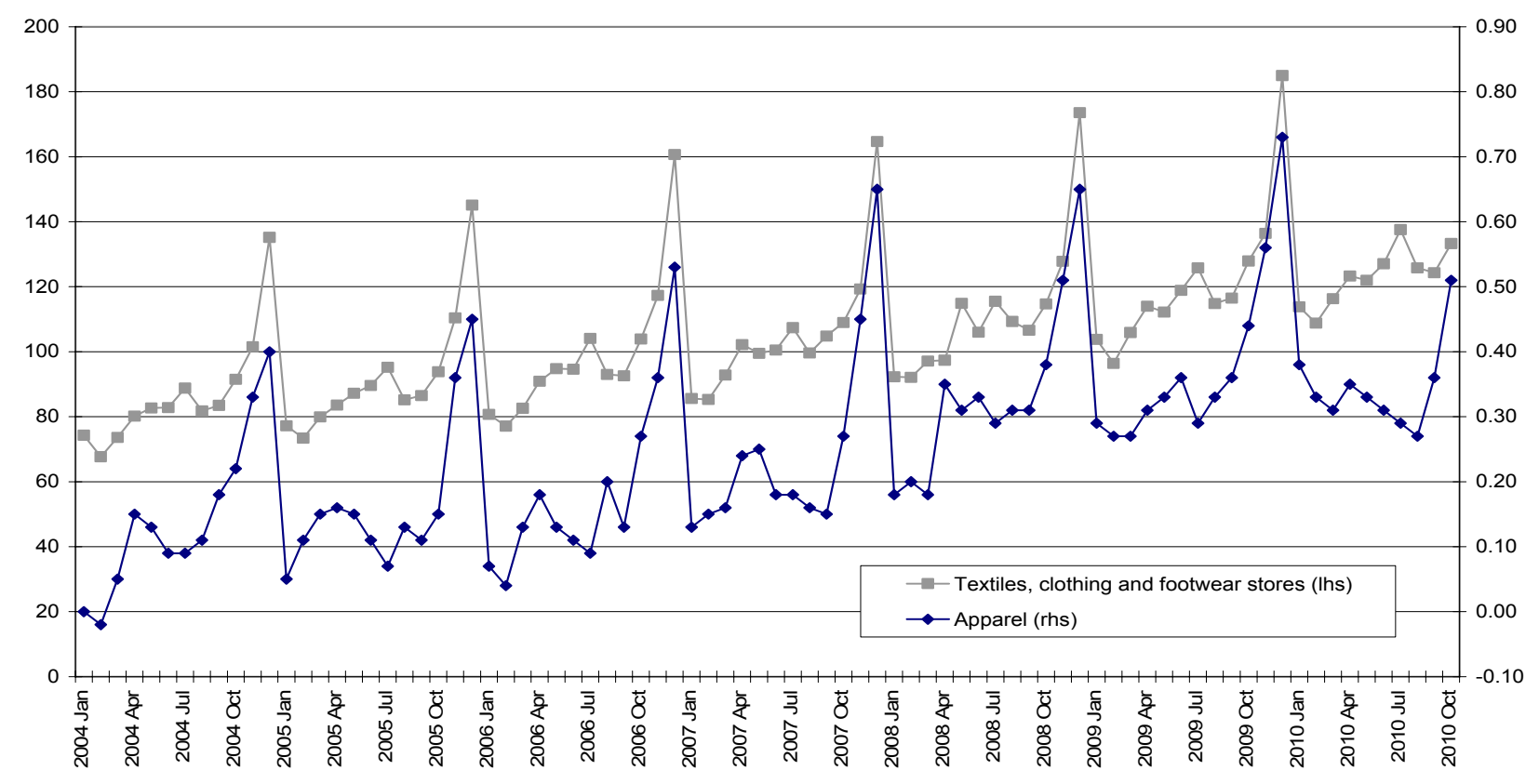

Source: ONS Retail Sales and Google Trends 
Dependent Variable: Textiles, clothing and footwear (large firms)

Sample: 2004M02 2010M10

\begin{tabular}{lllll} 
& Coefficient & Std. Error & t-Statistic & Prob. \\
Constant & -0.762260 & 0.070735 & -10.77632 & 0.0000 \\
Textiles, clothing and footwear (large firms) (-1) & -0.098986 & 0.036680 & -2.698638 & 0.0086 \\
Textiles, clothing and footwear (large firms) (-12) & 0.847713 & 0.064158 & 13.21287 & 0.0000 \\
Apparel & 0.284930 & 0.086051 & 3.311157 & 0.0014 \\
\hline
\end{tabular}

\section{Furniture and lighting}

The 'Lighting' Google Trends category was found to be the most significant variable in the regression model among the various possibilities. And as Figure 14 shows, there is a good correlation with movements in furniture and lighting retail sales. This is despite the top searches concentrating entirely on lighting (lighting, lights, lamps, bulbs and so on) with no coverage of furniture. Other Google Trends categories were insignificant in the regression, despite having top searches that might have been expected to be quite strongly correlated. For example, 'furniture' and 'Ikea' were the top two searches in both the 'Home and garden' and 'Home furnishings' categories. The 'Home making' category was also found to have limited significance, despite consisting of top searches such as blinds and curtains.

\section{Figure 14 Furniture and Lighting}

Retail Sales Index

Google Trends query share

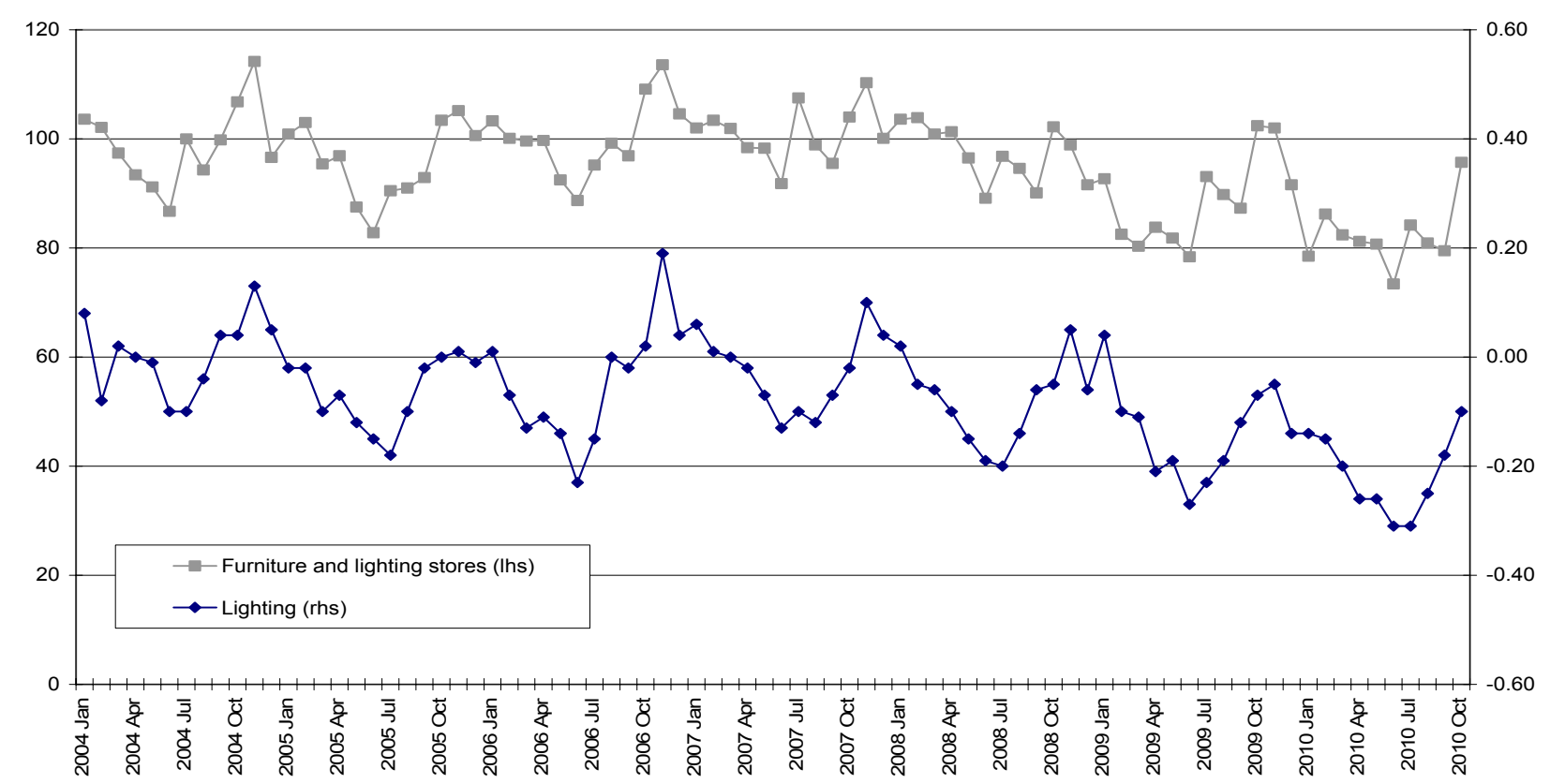

Source: ONS Retail Sales and Google Trends 


\begin{tabular}{lllll}
\hline Dependent Variable: Furniture and lighting & & & \\
\hline Sample: 2004M02 2010M10 & & & & \\
& Coefficient & Std. Error & t-Statistic & Prob. \\
Constant & -0.001585 & 0.005506 & -0.287879 & 0.7742 \\
Furniture and lighting (-1) & -0.238516 & 0.079849 & -2.987089 & 0.0038 \\
Furniture and lighting (-12) & 0.631267 & 0.085860 & 7.352289 & 0.0000 \\
Lighting & 0.315846 & 0.087907 & 3.592973 & 0.0006 \\
\hline
\end{tabular}

\section{Electrical household appliances}

On the face of it, retail sales of electrical household appliances have a strong association with the Google Trends category 'Home appliances' where the top searches consist of items like fridge, washing machine, oven, cookers, dishwasher and brands such as Hotpoint, Bosch, Dyson and Miele. However, as Figure 15 and the regression results show, the actual correlation is weak, with the Google Trends data not reflecting the very strong seasonal pattern in retail sales which seem to peak after Christmas. It may be the case that individuals use the Internet to obtain information on these products and brands throughout the year but wait for the sales period before making purchases. Or it may be the case that this information is obtained 'in-store' rather than online, with store visits themselves driven by end of year promotions.

\section{Figure 15 Household appliances}

Retail Sales Index

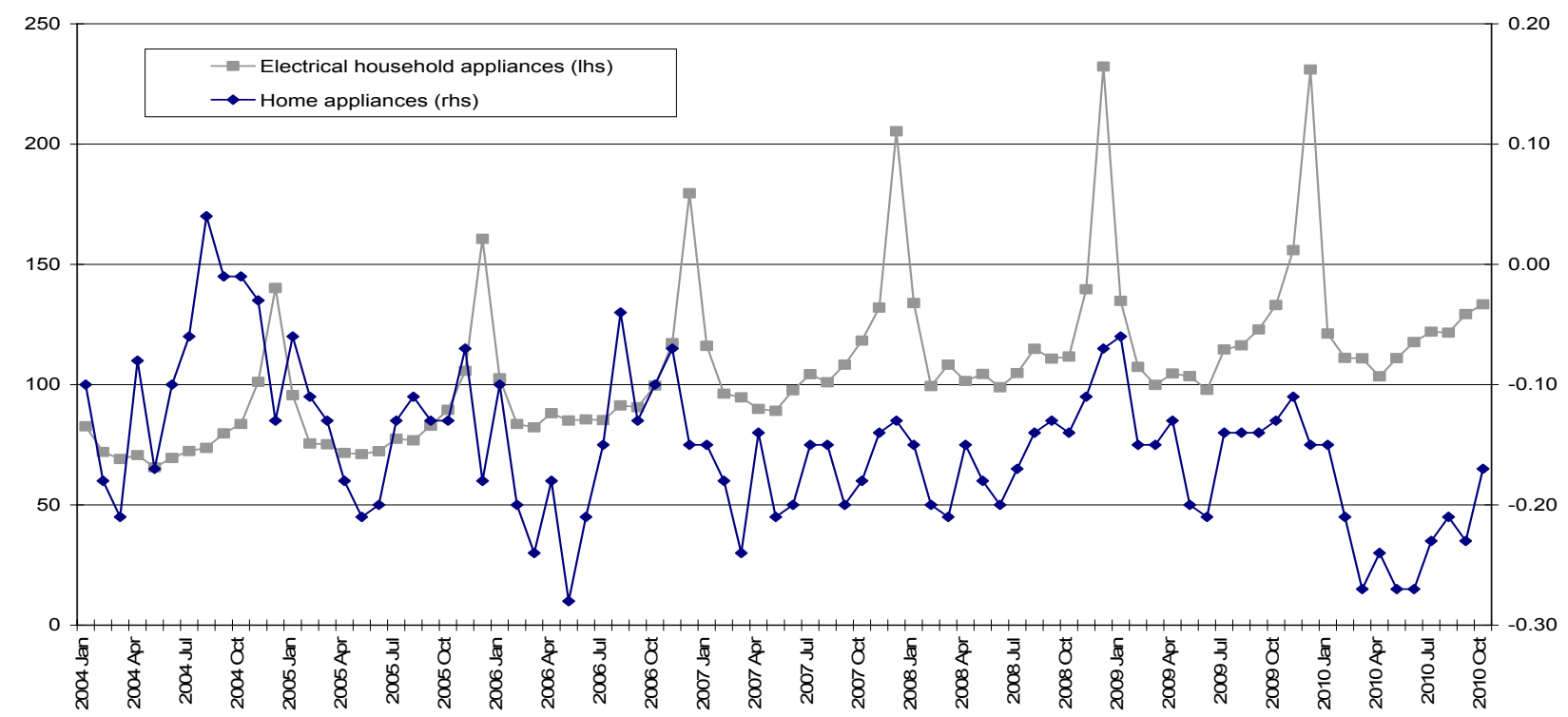

Source: ONS Retail Sales and Google Trends 
Dependent Variable: Electrical household appliances

Sample: 2004M02 2010M10

\begin{tabular}{lllll} 
& Coefficient & Std. Error & t-Statistic & Prob. \\
Constant & -0.001452 & 0.008180 & -0.177461 & 0.8596 \\
Electrical household appliances (-1) & -0.068132 & 0.042030 & -1.621050 & 0.1091 \\
Electrical household appliances (-12) & 0.960291 & 0.042651 & 22.51505 & 0.0000 \\
Home appliances & 0.062539 & 0.158712 & 0.394041 & 0.6946 \\
\hline
\end{tabular}

\section{Hardware, paint and glass}

The 'Home improvement' category in Google Trends shows a strong correlation with the shortterm movements in retail sales of Hardware, paint and glass (Figure 16) and reports a significant coefficient in the regression model. It is easy to see why when looking at the top searches which show the Google Trends 'Hardware' category to be strongly driven by B\&Q and Homebase - the UK's two largest DIY chains. Wickes and Focus also appear in the list of top searches with Wilkinsons and Screwfix among the rising searches meaning that the Google Trends indicator is strongly based on retailers.

\section{Figure 16 Hardware and Home improvement}

Retail Sales Index

Google Trends query share

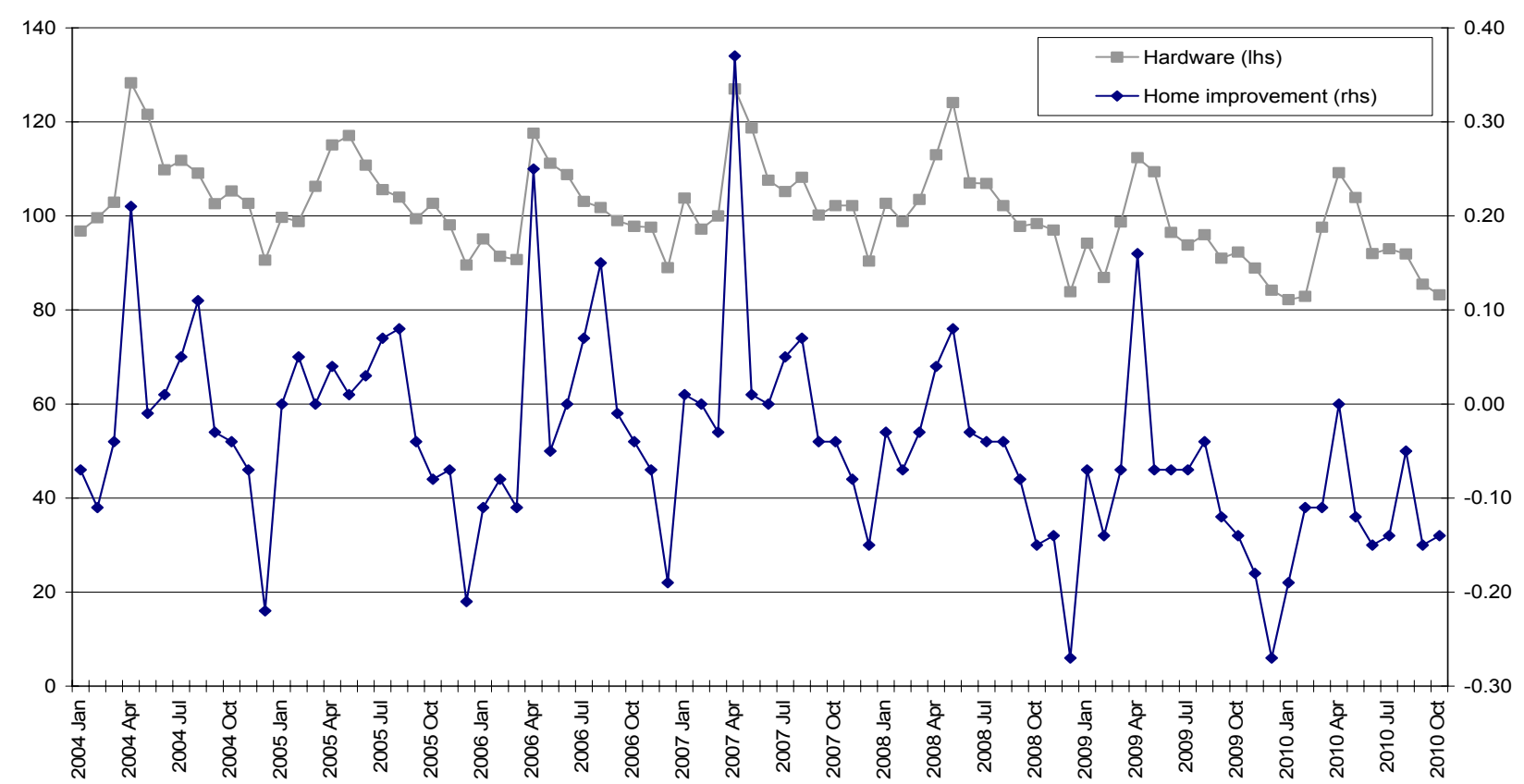

Source: ONS Retail Sales and Google Trends 


\begin{tabular}{lllll}
\hline Dependent Variable: Hardware & & & & \\
\hline Sample: 2004M02 2010M10 & & & & \\
& Coefficient & Std. Error & t-Statistic & Prob. \\
Constant & -0.001689 & 0.004952 & -0.341169 & 0.7339 \\
Hardware (-1) & 0.058889 & 0.065820 & 0.894694 & 0.3737 \\
Hardware (-12) & 0.512768 & 0.074151 & 6.915201 & 0.0000 \\
Home improvement & 0.318654 & 0.054996 & 5.794169 & 0.0000 \\
\hline
\end{tabular}

\section{Audio video equipment and recordings}

There are several Google Trends categories that may be related to this part of retail sales although none are very significant in the regression model. A combination of 'Music streams and downloads' and 'Music retailers', as shown in Figure 17, appears to be the best fit - although neither is significant at the 10 per cent level and both are insignificant if included individually. Whilst the 'Music retailers' category, consisting mainly of searches for HMV, shows a similar seasonal pattern to the retail sales data, its share of search queries has fallen since 2007. At the same time the volume of search queries in the 'Music streams and downloads' category (including iTunes) has risen but this has a less seasonal pattern.

\section{Figure 17 Audio video and Music retailing and downloads}

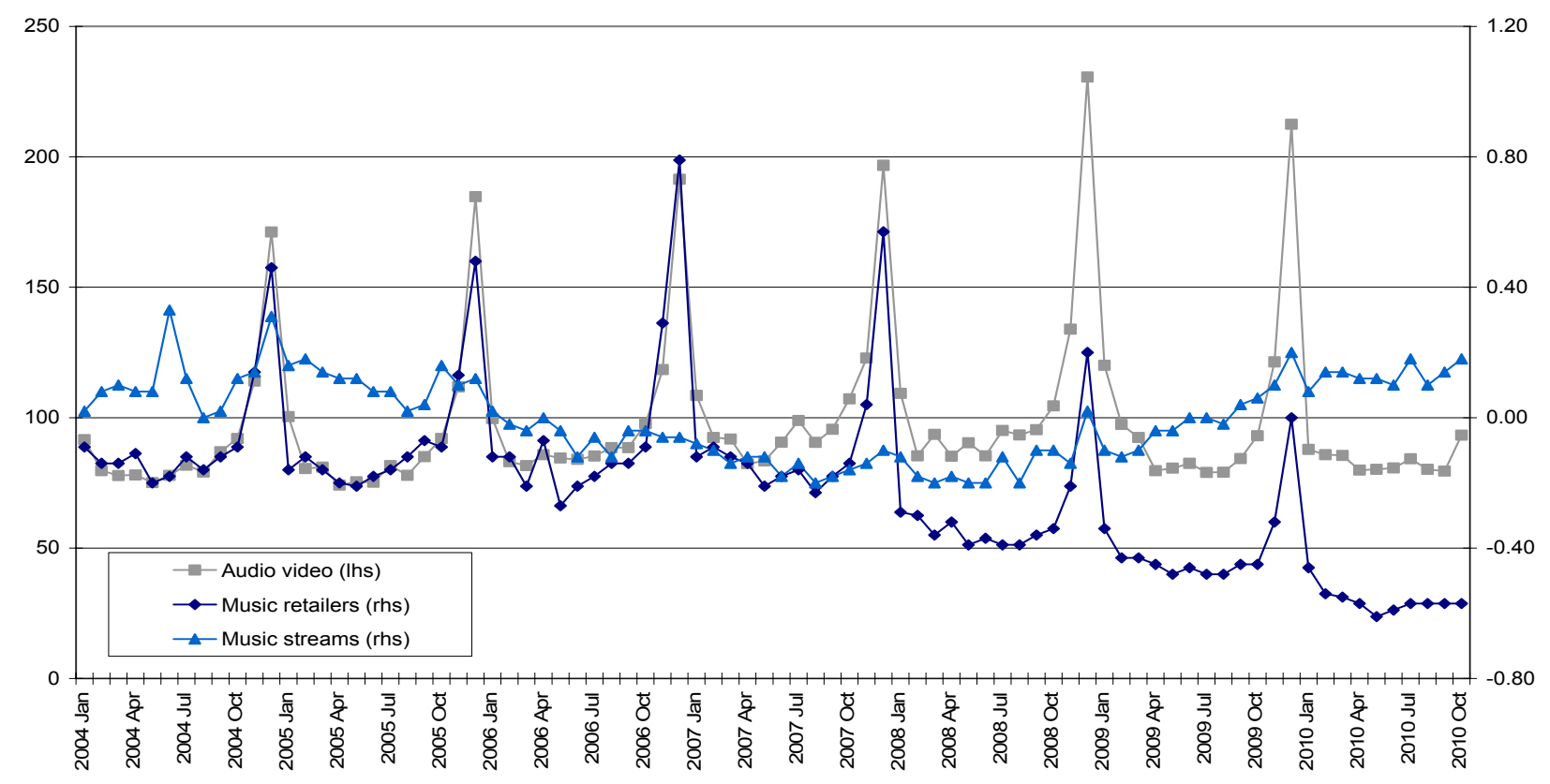

Source: ONS Retail Sales and Google Trends 


\begin{tabular}{lllll}
\hline Dependent Variable: Audio video & & & & \\
\hline Sample: 2004M02 2010M10 & & & & \\
& Coefficient & Std. Error & t-Statistic & Prob. \\
Constant & -0.000937 & 0.007889 & -0.118710 & 0.9058 \\
Audio video (-1) & -0.023859 & 0.035811 & -0.666242 & 0.5073 \\
Audio video (-12) & 0.867572 & 0.089219 & 9.724104 & 0.0000 \\
Music streams and downloads & 0.210392 & 0.128397 & 1.638600 & 0.1054 \\
Music retailers & 0.127788 & 0.087538 & 1.459801 & 0.1485 \\
\hline
\end{tabular}

A number of other Google Trends categories were considered but found to be insignificant. These include:

- 'Audio equipment' which is driven mainly by iPod and MP3 search queries

- 'Consumer electronics' which also includes iPods along with TV, Sony, LCD, Panasonic and Samsung in the top searches, and

- 'Home video' which also includes top searches of TV, LCD, Sony, Panasonic and Samsung

The lack of any retailers among the top and rising searches may explain why these have limited significance in a regression on retail sales.

\section{Books}

Retail sales in books, newspapers and stationery are shown in Figure 18 along with the Google Trends category 'Book retailers'. Clearly there is a strong correlation between the movements in each series and this is reflected in the regression model where the 'Book retailers' indicator is highly significant. The top searches are mainly focused around Amazon, although Waterstones and WH Smith also achieved a relatively high number of search queries. In the official retail sales data though Amazon is not categorised in books, newspapers and stationery but in non-store retailing. However, the evidence from the regression results suggest that it nonetheless still provides a good indicator of expenditure patterns. The same factors that may encourage people to go online and buy books from Amazon may also encourage purchases from other book stores. 


\section{Figure 18 Books and Book retailers}

Retail Sales Index

Google Trends query share

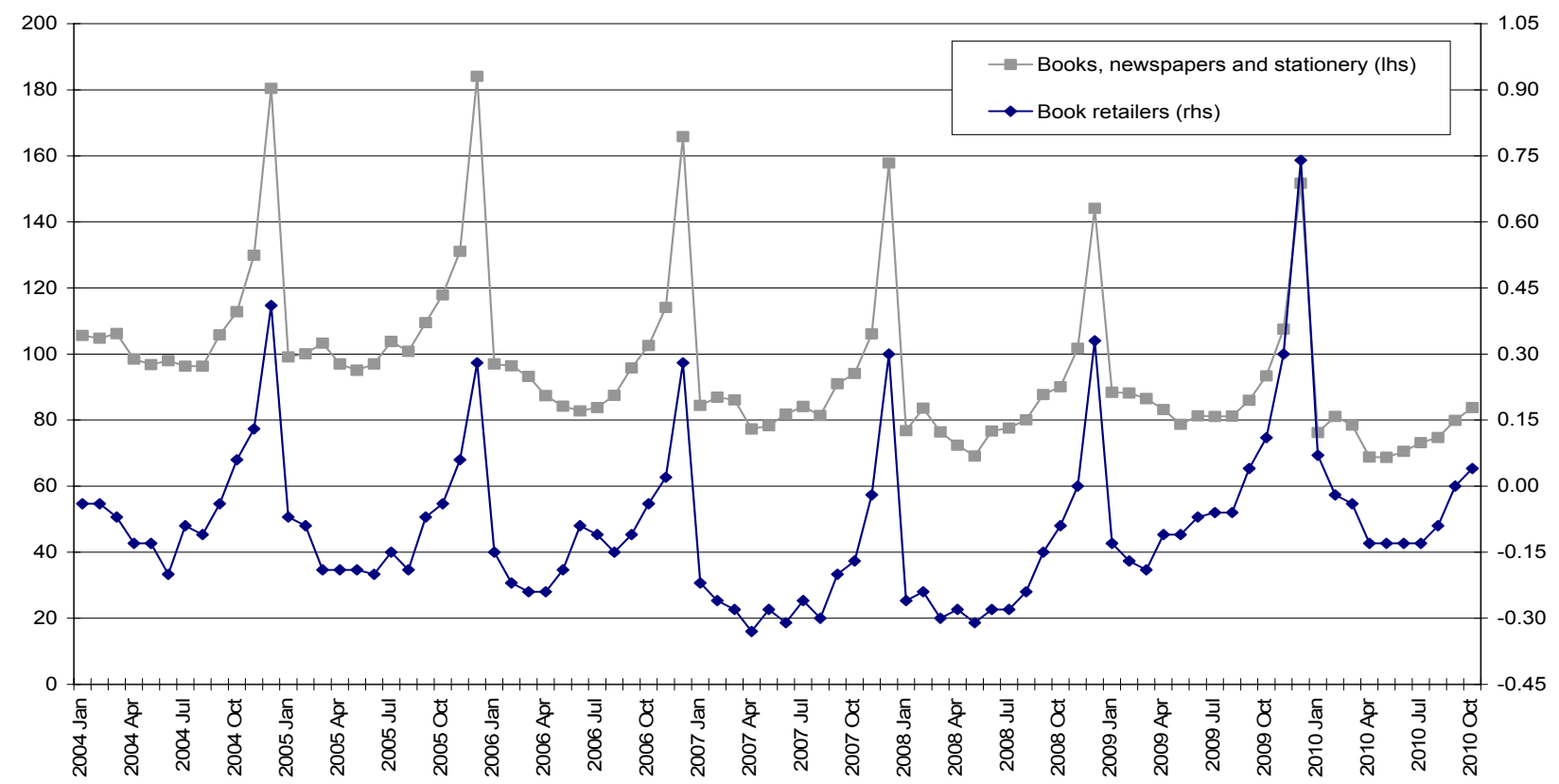

Source: ONS Retail Sales and Google Trends

\begin{tabular}{lllll}
\hline Dependent Variable: Books, newspapers and stationery & & & & \\
\hline Sample: 2004M02 2010M10 & & & & \\
& Coefficient & Std. Error & t-Statistic & Prob. \\
Constant & -0.003165 & 0.004873 & -0.649469 & 0.5180 \\
Books, newspapers and stationery (-1) & -0.064906 & 0.023838 & -2.722810 & 0.0080 \\
Books, newspapers and stationery (-12) & 0.551515 & 0.069803 & 7.901055 & 0.0000 \\
Book retailers & 0.521628 & 0.078090 & 6.679855 & 0.0000 \\
\hline
\end{tabular}

\section{Computers and telecommunications}

The Google Trends category 'Personal electronics' is found to be the most significant indicator of retail sales in computers and telecommunications. Top searches here are centred on small devises such as Palm, iPaq (an early Pocket PC), PDA and with Blackberry, iPhone and Windows mobile among the fastest rising searches. Figure 19 shows the value in using the difference approach in the regression model, as the falling share in total search queries may reflect an initially high share in 2004 although this downward trend has arrested since 2008, perhaps partly due to the release of the iPhone. The short-term movements in the series are clearly more correlated with the retail sales data than the longer term trends.

'Consumer electronics' was also considered but found to be insignificant as this consists mainly of audio video equipment. As can be seen in the Appendix, the 'Mobile and wireless', 'Mobile phones' 
and 'Telecommunications' categories all consist of broadly the same top searches (mobile, Nokia, O2, Samsung, Vodafone, Sony Ericsson, Carphone Warehouse and so on). These were also found to be significant in a regression on retail sales of computers and telecommunications but fitted less well than 'Personal electronics'.

\section{Figure 19 Computers and Personal electronics}

Retail Sales Index

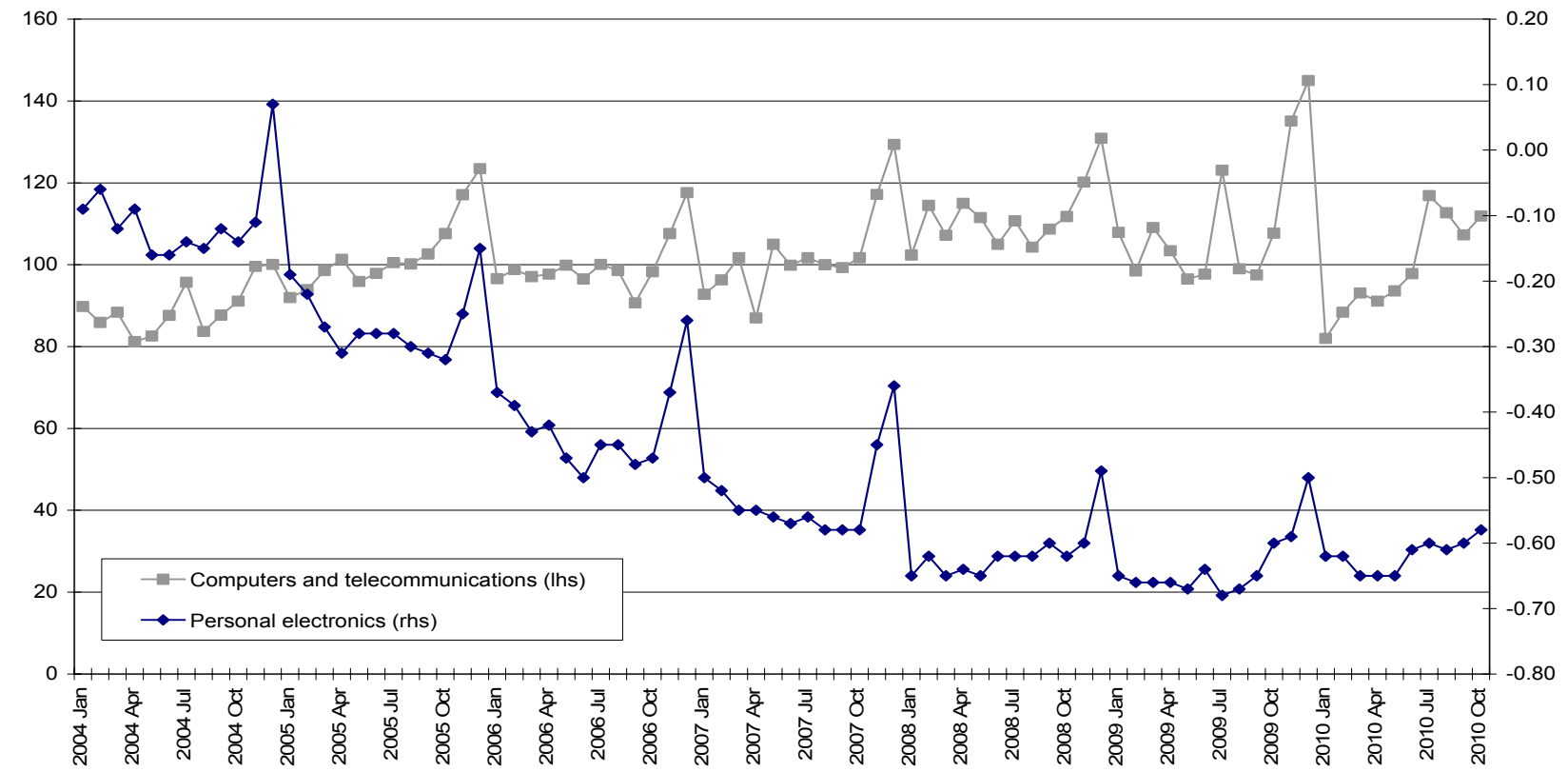

Source: ONS Retail Sales and Google Trends

\begin{tabular}{lllll}
\hline Dependent Variable: Computers and telecommunications & & & \\
\hline Sample: 2004M02 2010M10 & & & & \\
& Coefficient & Std. Error & t-Statistic & Prob. \\
Constant & 0.003214 & 0.009720 & 0.330611 & 0.7418 \\
Computers and telecommunications (-1) & -0.221568 & 0.084607 & -2.618779 & 0.0106 \\
Computers and telecommunications (-12) & 0.449533 & 0.125867 & 3.571500 & 0.0006 \\
Personal electronics & 0.556862 & 0.149354 & 3.728459 & 0.0004 \\
\hline
\end{tabular}

\section{Non-store retailing (large firms)}

Non-store retailing predominantly consists of mail order and market stalls, but the large firms time series is unlikely to consist of too many of the latter. The 'Shopping portals and search engine' category in Google Trends is found to exhibit similar movements and is significant in the regression model (see Figure 20). This category is dominated by catalogue-based retailers including Argos, Littlewoods, Additions and Empire. Although Argos operates a mail-order business, most of its 
activity is still in store retailing so it is not classified in the non-store category. However, it may well still, provide a good proxy for activity in this part of retail sales.

\section{Figure 20 Non-store retailing and shopping portals}

Retail Sales Index

Google Trends query share

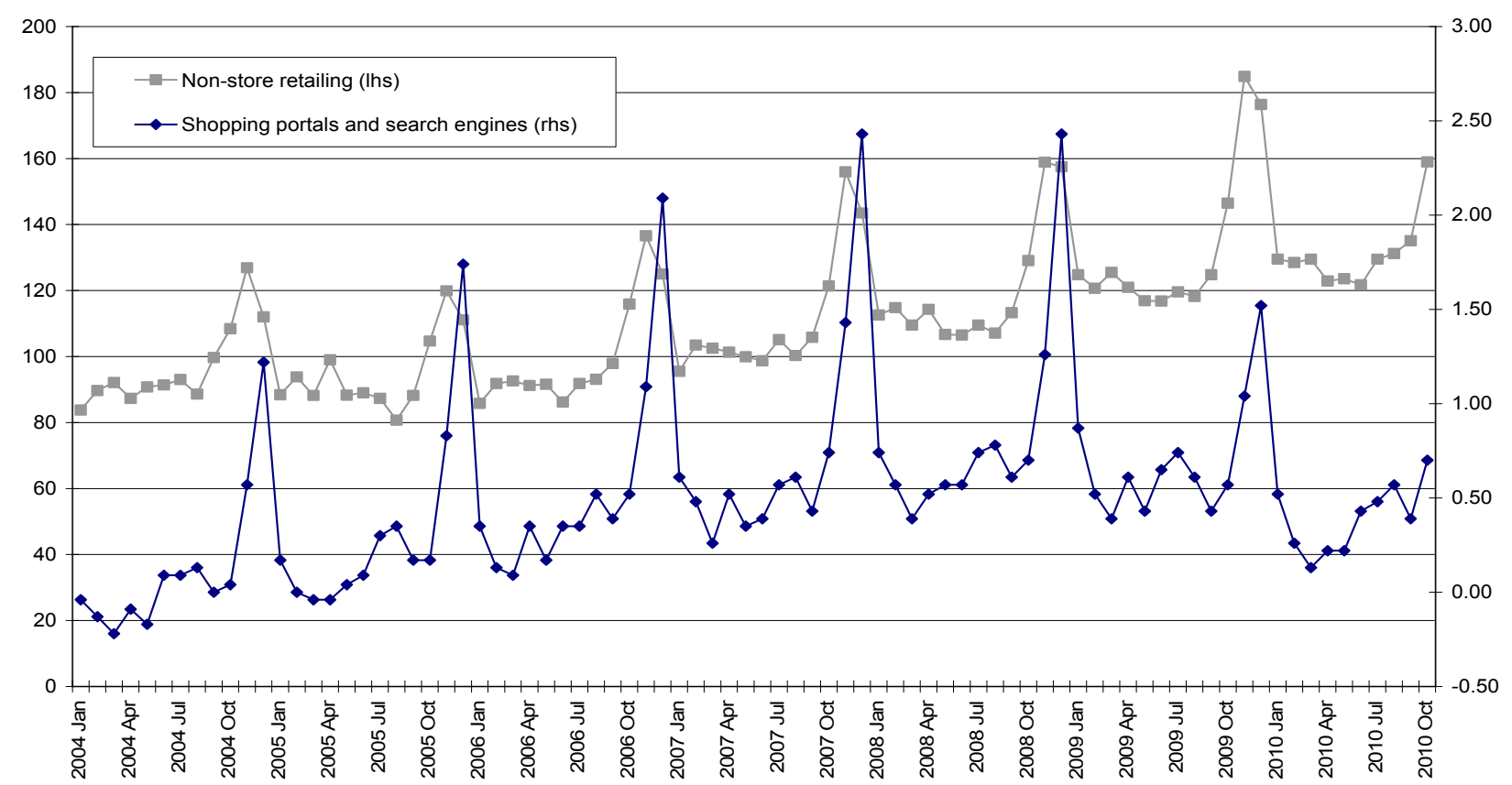

Source: ONS Retail Sales and Google Trends

\begin{tabular}{lllll}
\hline Dependent Variable: Non-store retailing (large firms) & & & & \\
\hline Sample: 2004M02 2010M10 & & & & \\
& Coefficient & Std. Error & t-Statistic & Prob. \\
Constant & 0.001096 & 0.005620 & 0.194989 & 0.8459 \\
Non-store retailing (large firms) (-1) & -0.070876 & 0.063717 & -1.112358 & 0.2694 \\
Non-store retailing (large firms) (-12) & 0.809537 & 0.062435 & 12.96605 & 0.0000 \\
Shopping portals and search engines & 0.039925 & 0.016244 & 2.457776 & 0.0162 \\
\hline
\end{tabular}

\section{Motor car registrations}

Data on car registrations comes from the DVLA. Figure 21 shows this to follow a very distinct seasonal pattern, with peaks in March and September each year coinciding with the latest new registration. Google Trends data on 'Vehicle licensing and registration' includes DVLA as the highest search, but does not match the strong seasonal pattern in the DVLA data and is insignificant in the regression. In fact the twelve month lag of the dependent variable itself is found to have a coefficient close to unity, implying that the time series is strongly related to its own past 
seasonal behaviour. Car registration is ranked fairly low among the search queries making up the 'Vehicle licensing and registration' category which might explain its low significance. Other aspects of DVLA business including number plates, licensing and tax were also found to be among the top searches and show that the category consists of a broader array of search queries than just car registrations.

\section{Figure 21 Car registrations and Vehicle licensing and registrations}

Car registrations (thousands)

Google Trends query share

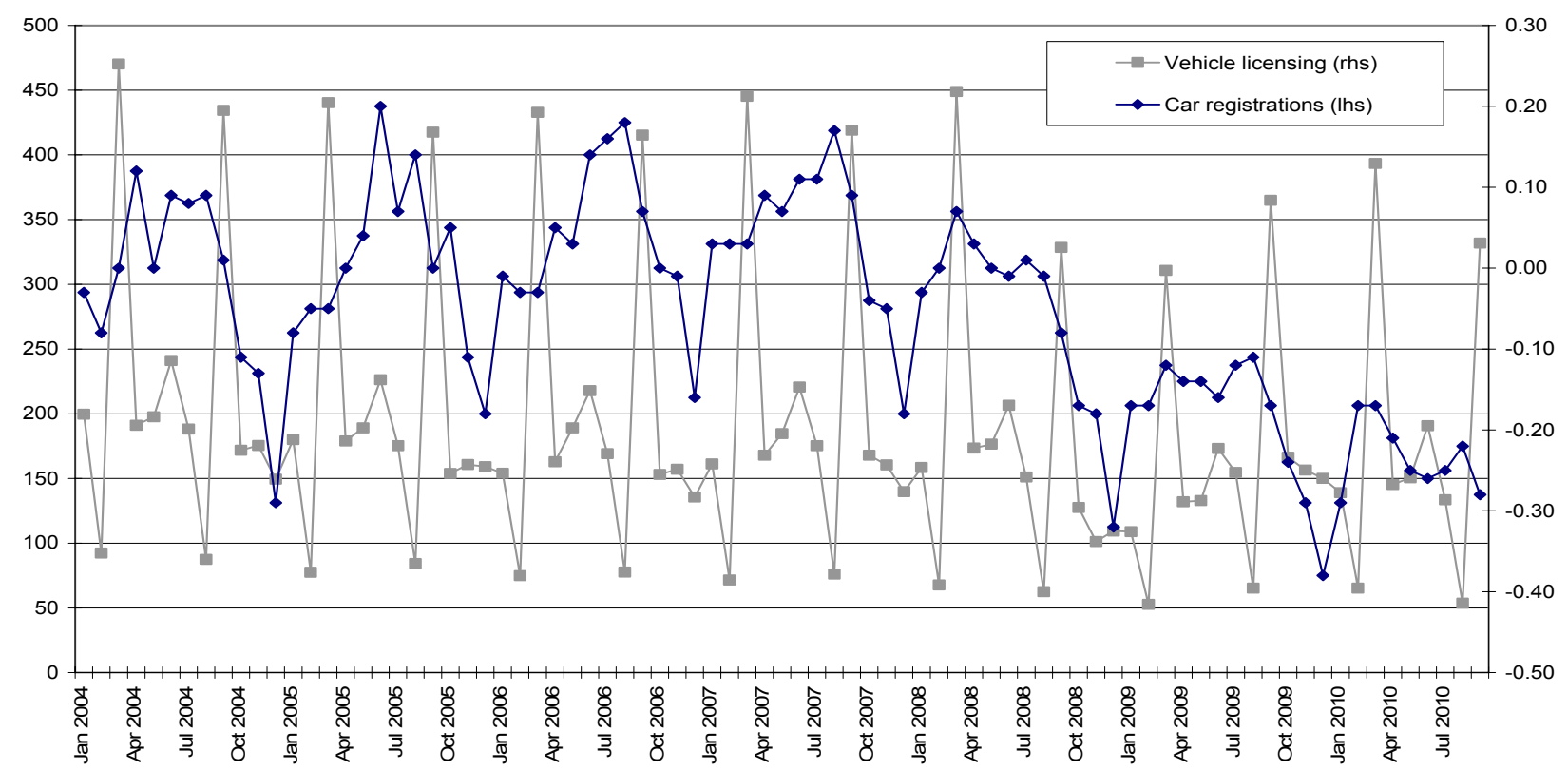

Source: DVLA Car Registrations and Google Trends

\begin{tabular}{lllll}
\hline Dependent Variable: Car registrations (DVLA) & & & & \\
\hline Sample: 2004M02 2010M09 & & & & \\
& Coefficient & Std. Error & t-Statistic & Prob. \\
Constant & -0.002254 & 0.010093 & -0.223284 & 0.8239 \\
Car registrations (DVLA) (-1) & -0.002951 & 0.015267 & -0.193269 & 0.8473 \\
Car registrations (DVLA) (-12) & 1.008680 & 0.015127 & 66.67939 & 0.0000 \\
Vehicle licensing and registrations & -0.180889 & 0.121163 & -1.492935 & 0.1396 \\
\hline
\end{tabular}

Testing Google Trends data as an explanatory variable for motor car sales would be more interesting than registrations. Choi and Varian (2009) do just this in their paper by investigating the relationship between sales and query shares for different vehicle brands.

There are a number of Google Trends categories which may be useful for analysing car sales, including: 
- 'Vehicle shopping' - with Autotrader as the top search

- 'Vehicle brands' - which includes all the main vehicle manufacturers among the top searches

- 'Auto financing' - with top searches orientated towards leasing arrangements, and

- 'Automotive' - a general top level category of search queries

Monthly data on car sales in the UK is published by the Society of Motor Manufacturers and Traders (SMMT) although it is not made freely available to the public. Alternative sources of data might include quarterly spending on motor cars reported in ONS Consumer Trends, and the output of the distribution of motor vehicles industry in the monthly Index of Services.

\section{Property transactions}

The number of property transactions each month in England and Wales over $£ 40,000$ is published by the Land Registry. Google Trends data that are found to be significant include the categories of 'Real estate' and 'Home inspections and appraisals' (Figure 22). Top searches in the 'Real estate' category are estate agents, with the property website Rightmove not far behind. Other key words such as property, houses and mortgage also feature highly. Price comparison and property search websites feature among the rising searches, reflecting the increasing role the Internet is playing in both searching for properties and in finding the best financing options. The 'Home inspections and appraisals' category is a logical choice of indicator as these are usually carried out prior to transactions being completed.

\section{Figure 22 Property transactions and Real estate}

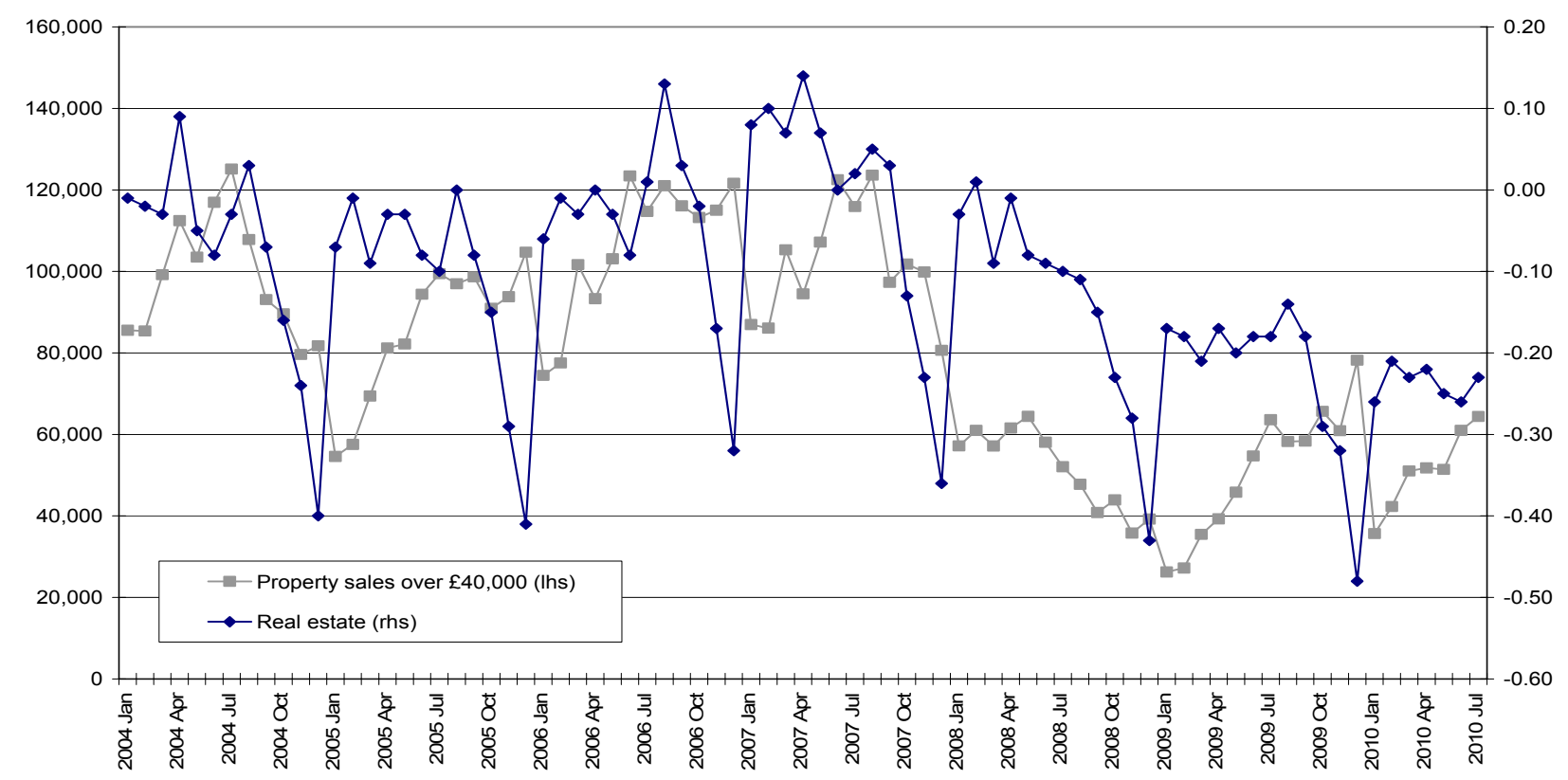

Source: Land Registry and Google Trends 


\begin{tabular}{lllll}
\hline Dependent Variable: Property sales (Land Registry) & & & & \\
\hline Sample: 2004M02 2010M07 & Coefficient & Std. Error & t-Statistic & Prob. \\
& -0.003316 & 0.013665 & -0.242686 & 0.8089 \\
Constant & -0.157477 & 0.079126 & -1.990209 & 0.0503 \\
Property sales (Land Registry) (-1) & 0.619341 & 0.115115 & 5.380191 & 0.0000 \\
Property sales (Land Registry) (-12) & -0.284405 & 0.145466 & -1.955129 & 0.0544 \\
Real estate & -0.286356 & 0.105654 & -2.710324 & 0.0084 \\
Home inspections and appraisals & &
\end{tabular}

\section{Mortgage applications}

The number of mortgage approvals for house purchase is published each month by the Bank of England and relates to the Google Trends category of 'Home financing'. However, in the regression, a lag of the Google Trends data is found to be more significant than if the variable entered the regression contemporaneously which is evident in Figure 23. This probably reflects the time period between searching and approval when mortgage applications are completed and then processed (for example credit checks, proof of income, homebuyer surveys and so on). Price comparison websites like moneysupermarket.com are among both the top and rising searches.

\section{Figure 23 Mortgage approvals and home financing}

Number of mortgage approvals

Google Trends query share

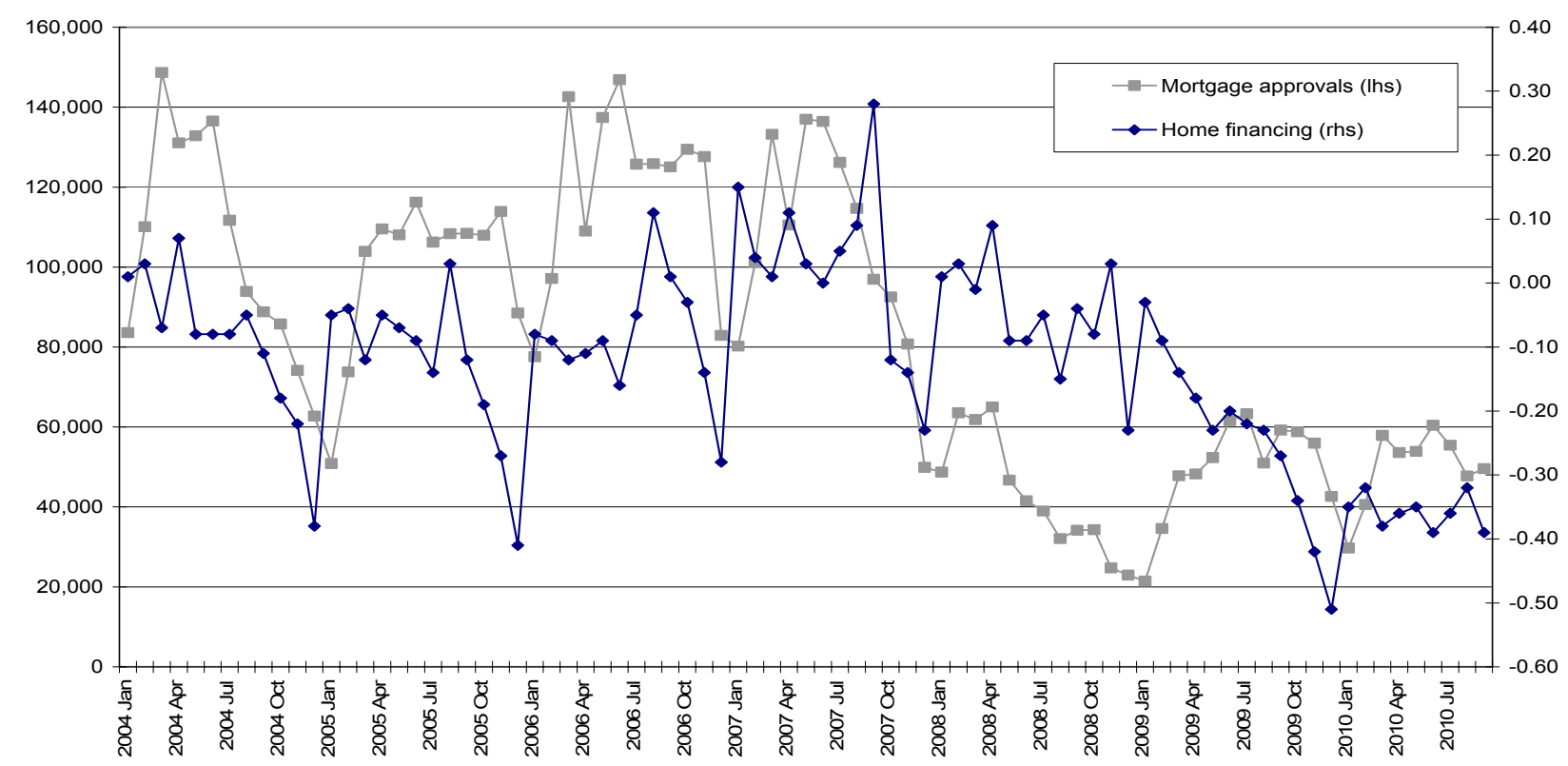

Source: Bank of England Monetary and Financial Statistics and Google Trends 


\begin{tabular}{lllll}
\hline Dependent Variable: Mortgage approvals (Bank of England) & & & & \\
& & & & \\
Sample: 2004M02 2010M09 & Coefficient & Std. Error & t-Statistic & Prob. \\
Constant & -0.005760 & 0.016813 & -0.342565 & 0.7329 \\
Mortgage approvals (Bank of England) (-1) & 0.060705 & 0.089004 & 0.682042 & 0.4973 \\
Mortgage approvals (Bank of England) (-12) & 0.575170 & 0.102099 & 5.633439 & 0.0000 \\
Home financing (-1) & 0.280539 & 0.149869 & 1.871891 & 0.0651 \\
\hline
\end{tabular}

It should also be noted that not all Internet searches for home financing necessarily lead to approvals as factors on both the supply and demand side of financial markets are important. For example, a tightening in lending conditions, as appears to be the case now, may lower the correlation between volumes of search queries and eventual approvals. The data in Figure 23 tends to show a sharper fall in mortgage approvals than 'Home financing' queries at the height of the financial crisis in the second half of 2008. Queries could fall with a slight lag relative to approvals as potential borrowers may not be immediately aware of changes in lending conditions.

\section{International travel and tourism}

ONS's monthly Travel and tourism statistical bulletin reports on the number of visits overseas by UK residents and their expenditure as collected from the International Passenger Survey (IPS). Several Google Trends categories report on queries relating to this activity. 'Travel' is a high level category consisting of search items like hotel, flights, holidays, trains and travel. Top searches in 'Vacation destinations' are New York, Las Vegas, Paris, Orlando, Barbados and Disneyland. In their article, Choi and Varian (2009) test the number of visits to Hong Kong as reported monthly by the Hong Kong Tourism Board against the 'Hong Kong' subcategory under 'Vacation destinations' and find a positive and significant relationship. 'Hotels and accommodation' is strongly concentrated in hotel chains with the Trip Advisor website among the rising searches. 'Air travel' picks up on queries for (cheap) flights, Easyjet, Ryan Air, British Airways among the top searches. And 'Cruises and charters' focuses on water transport with top searches including cruises, ferries, P\&O, Royal Caribbean and Stena.

Despite there being a number of relevant Google Trends categories none were found to be significant in a regression with numbers of foreign trips, although the 'Travel' category does show similar seasonal movements (Figure 24). Other monthly data that might be worth testing with these indicators could be the output of the Air transport industry in the Index of Services and Airport passenger numbers as reported by the Civil Aviation Authority. 


\section{Figure $24 \quad$ Foreign trips and Travel}

Number of foreign trips by UK residents

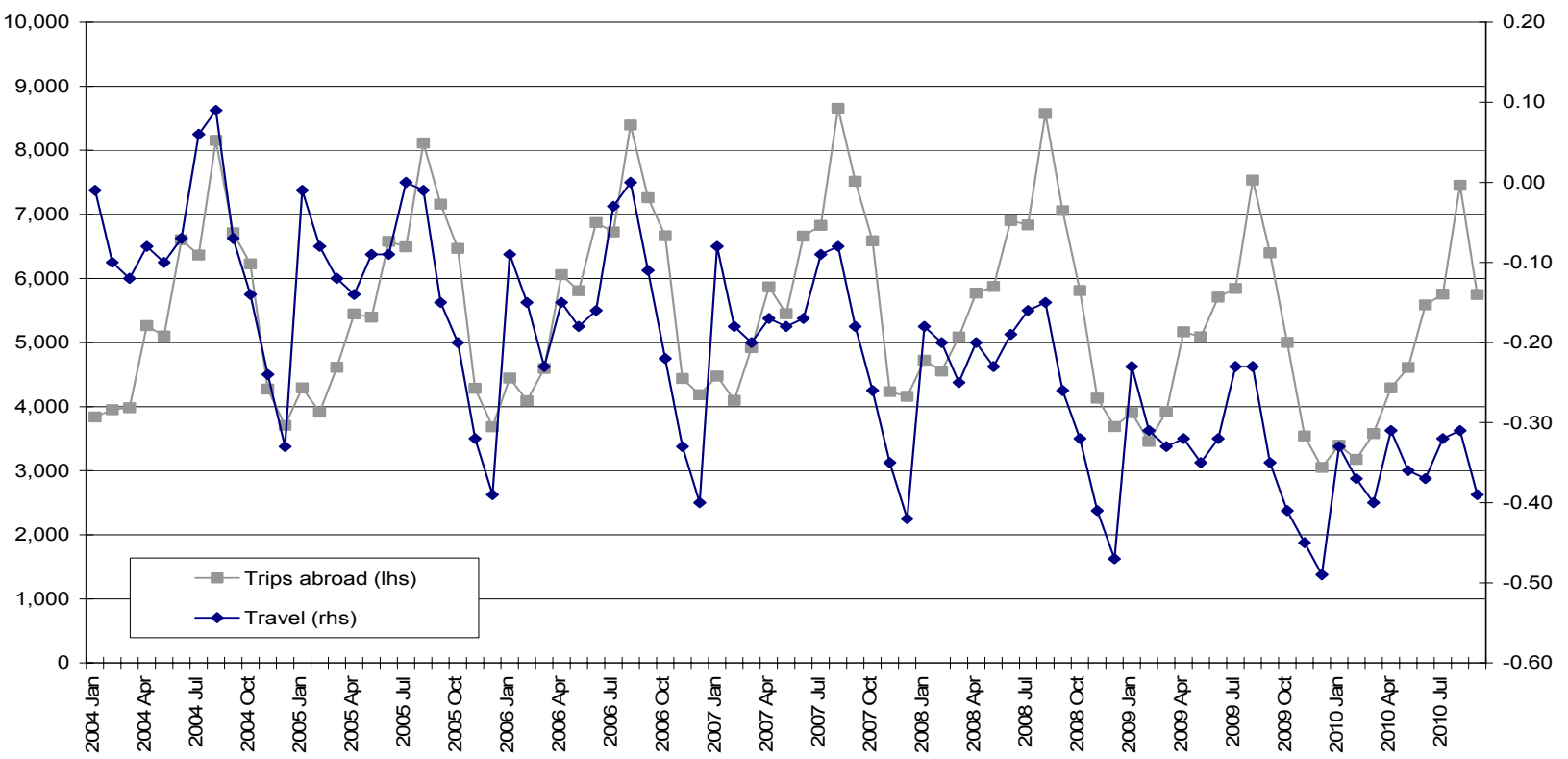

Source: ONS Travel and Tourism (IPS) and Google Trends

\begin{tabular}{|c|c|c|c|c|}
\hline \multicolumn{5}{|c|}{ Dependent Variable: Visits abroad (IPS) } \\
\hline \multicolumn{5}{|c|}{ Sample: 2004M02 2010M09 } \\
\hline & Coefficient & Std. Error & t-Statistic & Prob. \\
\hline Constant & -0.001077 & 0.007636 & -0.140976 & 0.8883 \\
\hline Visits abroad (IPS) (-1) & -0.027541 & 0.043301 & -0.636027 & 0.5267 \\
\hline Visits abroad (IPS) (-12) & 0.930934 & 0.051045 & 18.23764 & 0.0000 \\
\hline Travel & 0.083728 & 0.089440 & 0.936140 & 0.3522 \\
\hline
\end{tabular}

\section{Conclusions}

This article has outlined the increasing use of the Internet by UK individuals and businesses as a means for finding out information and purchasing goods and services. It has then investigated whether the search queries made by people in a geographic area bear any resemblance to actual reported activity. As this search data from Google Trends is available in real time, any significant relationship could be potentially exploited for nowcasting. Google Trends data may also be used informally to pick up on changing patterns and rising trends in search queries and the implications they have for types of economic activity and spending. 
Google Trends arranges search queries into categories, but the use is not just limited to these. Any user can form their own indicators, consisting of either individual or groups of search queries - and this may be particularly useful. For example, this article has found that Google Trends categories where large retailers are among the top searches are often significant indicators in a regression with retail sales. Therefore, composite indicators formed from search queries of major retailers or providers of goods and services in a particular field may provide useful advance information on changing patterns of spending.

\section{Further information}

Internet Access - shows information about both households with home access to the Internet and individuals' use of the Internet.

www.statistics.gov.uk/StatBase/Product.asp?vlnk=5672

E-Commerce - describes the use of Information and Communication Technology (ICT) and ecommerce activity by UK businesses.

www.statistics.gov.uk/statbase/Product.asp?vlnk=6645

Google Trends - Google Insights for Search can be used to compare search volume patterns across specific regions, categories, time frames and properties.

www.google.com/insights/search/

\section{Contact}

elmr@ons.gov.uk

\section{References}

Choi H and Varian H (2009) 'Predicting the present with Google Trends', Google Inc, available at http://static.googleusercontent.com/external_content/untrusted_dlcp/www.google.com/en//googlebl ogs/pdfs/google_predicting_the_present.pdf

McLaren C (2009) 'An experimental measure of Internet retail sales: changes to methods', available at www.statistics.gov.uk/cci/article.asp?ID=2358

Wallis G (2006) 'Internet spending: measurement and recent trends', Economic Trends, March 2006, pp 65-75, available at www.statistics.gov.uk/cci/article.asp?ID=1449 
Appendix: Top and rising searches in Google Trends categories

\begin{tabular}{|c|c|c|c|c|c|c|c|}
\hline \multirow{2}{*}{$\begin{array}{l}\text { Shopping } \\
\text { All retailing (large firms) }\end{array}$} & & \multicolumn{2}{|l|}{ Food retailers } & \multicolumn{2}{|c|}{$\begin{array}{l}\text { Mass merchants and department } \\
\text { stores }\end{array}$} & \multicolumn{2}{|l|}{ Apparel } \\
\hline & & \multicolumn{2}{|c|}{$\begin{array}{l}\text { Non-specialised food stores } \\
\text { (large firms) }\end{array}$} & \multicolumn{2}{|c|}{ Non-specialised non-food stores } & \multicolumn{2}{|c|}{$\begin{array}{l}\text { Textiles, clothing and } \\
\text { footwear (large firms) }\end{array}$} \\
\hline Top searches & & Top searches & & Top searches & & Top searches & \\
\hline ebay & 100 & tesco & 100 & marks spencer & 100 & shoes & 100 \\
\hline argos & 35 & asda & 50 & john lewis & 95 & boots & 75 \\
\hline ebay uk & 25 & tesco direct & 15 & marks and spencer & 85 & dress & 55 \\
\hline next & 20 & morrisons & 10 & debenhams & 75 & clothes & 45 \\
\hline shoes & 15 & sainsburys & 10 & times & 60 & next & 40 \\
\hline boots & 10 & aldi & 5 & next & 45 & dresses & 35 \\
\hline debenhams & 10 & clubcard & 5 & river island & 45 & nike & 35 \\
\hline dress & 10 & george asda & 5 & $m \& s$ & 25 & river island & 35 \\
\hline john lewis & 10 & lidl & 5 & marks spencers & 25 & watches & 35 \\
\hline marks and spencer & 10 & ocado & 5 & woolworths & 25 & new look & 30 \\
\hline river island & 10 & sainsbury & 5 & dorothy perkins & 20 & watch & 30 \\
\hline topshop & 10 & supermarket & 5 & marks and spencers & 20 & asos & 25 \\
\hline amazon & 5 & tesco clubcard & 5 & matalan & 20 & fancy dress & 25 \\
\hline dresses & 5 & tesco online & 5 & next directory & 20 & topshop & 25 \\
\hline fancy dress & 5 & tesco uk & 5 & miss selfridge & 15 & adidas & 20 \\
\hline littlewoods & 5 & tescos & 5 & costco & 10 & debenhams & 20 \\
\hline new look & 5 & waitrose & 5 & great universal & 10 & bags & 15 \\
\hline nike & 5 & asda direct & 0 & harrods & 10 & dorothy perkins & 15 \\
\hline shopping & 5 & asda uk & 0 & kays & 10 & monsoon & 15 \\
\hline watches & 5 & online shopping & 0 & marks \& spencer & 10 & trainers & 15 \\
\hline Rising searches & & Rising searches & & Rising searches & & Rising searches & \\
\hline new look & $300 \%$ & asda direct & $4250 \%$ & $\mathrm{~m}$ and $\mathrm{s}$ & $400 \%$ & asos & $950 \%$ \\
\hline river island & $200 \%$ & tesco direct & $2900 \%$ & next sale & $250 \%$ & new look & $300 \%$ \\
\hline amazon & $150 \%$ & tesco deals & $1100 \%$ & $m \& s$ & $170 \%$ & river island & $250 \%$ \\
\hline topshop & $120 \%$ & tesco clubcard & $400 \%$ & river island & $150 \%$ & dorothy perkins & $170 \%$ \\
\hline next & $80 \%$ & clubcard & $350 \%$ & times & $110 \%$ & monsoon & $170 \%$ \\
\hline ebay & $70 \%$ & asda online & $190 \%$ & miss selfridge & $90 \%$ & topshop & $160 \%$ \\
\hline ebay uk & $70 \%$ & george asda & $80 \%$ & dorothy perkins & $80 \%$ & debenhams & $130 \%$ \\
\hline littlewoods & $70 \%$ & asda & $50 \%$ & halfords & $70 \%$ & next & $130 \%$ \\
\hline dress & $60 \%$ & sainsburys & $50 \%$ & next & $50 \%$ & dresses & $80 \%$ \\
\hline dresses & $60 \%$ & ocado & $40 \%$ & next directory & $40 \%$ & dress & $60 \%$ \\
\hline
\end{tabular}




\begin{tabular}{|c|c|c|c|c|c|c|c|}
\hline \multirow{2}{*}{\multicolumn{2}{|c|}{$\begin{array}{l}\text { Clothing retailers } \\
\text { Textiles, clothing and footwear (large } \\
\text { firms) }\end{array}$}} & \multirow{2}{*}{\multicolumn{2}{|c|}{$\begin{array}{l}\text { Clothing labels and designers } \\
\begin{array}{l}\text { Textiles, clothing and footwear } \\
\text { (large firms) }\end{array}\end{array}$}} & \multirow{2}{*}{\multicolumn{2}{|c|}{$\begin{array}{l}\text { Lighting } \\
\text { Furniture and lighting }\end{array}$}} & \multicolumn{2}{|c|}{ Home and garden } \\
\hline & & & & & & Furniture and & ighting \\
\hline \multicolumn{2}{|l|}{ Top searches } & \multicolumn{2}{|l|}{ Top searches } & \multicolumn{2}{|l|}{ Top searches } & \multicolumn{2}{|c|}{ Top searches } \\
\hline urban & 100 & jeans & 100 & lighting & 100 & furniture & 100 \\
\hline urban outfitters & 75 & abercrombie & 95 & lights & 40 & ikea & 95 \\
\hline bicester & 50 & fitch & 70 & lamp & 30 & $b \& q$ & 65 \\
\hline bicester village & 40 & zara & 65 & bulbs & 25 & homebase & 60 \\
\hline mcarthur glen & 20 & abercrombie fitch & 60 & lamps & 25 & argos & 40 \\
\hline designer outlet & 15 & abercrombie and fitch & 50 & light bulbs & 15 & $\mathrm{~b} \mathrm{q}$ & 40 \\
\hline marshalls & 15 & north face & 50 & fluorescent & 10 & beds & 30 \\
\hline outlet village & 15 & gap & 45 & halogen & 10 & kitchen & 30 \\
\hline roupas & 15 & diesel & 35 & light bulb & 10 & diy & 25 \\
\hline ashford & 10 & hollister & 35 & ceiling light & 5 & $b$ and $q$ & 20 \\
\hline ashford outlet & 10 & superdry & 35 & ceiling lights & 5 & blinds & 20 \\
\hline bicester outlet & 10 & karen millen & 30 & energy saving bulbs & 5 & john lewis & 20 \\
\hline bicester shopping & 10 & nike & 30 & garden lights & 5 & kitchens & 20 \\
\hline clothing stores & 10 & vans & 30 & gu10 & 5 & lighting & 20 \\
\hline gap kids & 10 & armani & 25 & light fitting & 5 & sofa & 20 \\
\hline outlet swindon & 10 & burberry & 25 & light fittings & 5 & sofa sofa & 20 \\
\hline urban rivals & 10 & hartlepool & 25 & lighting uk & 5 & wickes & 20 \\
\hline bicester shopping village & 5 & paul smith & 25 & solar lights & 5 & focus & 15 \\
\hline mens clothing & 5 & hugo boss & 20 & thorn & 5 & fridge & 15 \\
\hline vintage clothing & 5 & reebok & 20 & wall lights & 5 & $\mathrm{mfi}$ & 15 \\
\hline \multicolumn{2}{|l|}{ Rising searches } & \multicolumn{2}{|l|}{ Rising searches } & \multicolumn{2}{|l|}{ Rising searches } & \multicolumn{2}{|c|}{ Rising searches } \\
\hline roupa & Breakout & superdry & $3250 \%$ & energy saving bulbs & $160 \%$ & next & $160 \%$ \\
\hline roupas & Breakout & hollister & $750 \%$ & gu10 & $140 \%$ & argos & $90 \%$ \\
\hline urban rivals & Breakout & h\&m & $200 \%$ & led bulbs & $130 \%$ & ikea uk & $70 \%$ \\
\hline urban & $180 \%$ & aldo & $160 \%$ & led lights & $110 \%$ & $\mathrm{~b}$ and $\mathrm{q}$ & $60 \%$ \\
\hline urban outfitters & $160 \%$ & abercrombie and fitch & $140 \%$ & lamp shades & $100 \%$ & john lewis & $60 \%$ \\
\hline hollister clothing & $150 \%$ & karen millen & $120 \%$ & ceiling light & $90 \%$ & laura ashley & $50 \%$ \\
\hline vero moda & $110 \%$ & abercrombie & $90 \%$ & ceiling lights & $60 \%$ & curtains & $40 \%$ \\
\hline bista village & $70 \%$ & fitch & $80 \%$ & solar lights & $60 \%$ & homebase & $40 \%$ \\
\hline urbanoutfitters & $70 \%$ & abercrombie fitch & $70 \%$ & table lamp & $50 \%$ & mattress & $40 \%$ \\
\hline banana republic & $50 \%$ & fred perry & $70 \%$ & light fitting & $40 \%$ & & \\
\hline
\end{tabular}




\begin{tabular}{|c|c|c|c|c|c|c|c|}
\hline \multirow{2}{*}{$\begin{array}{l}\text { Home making } \\
\text { Furniture and lighting }\end{array}$} & & \multicolumn{2}{|l|}{ Home furnishings } & \multicolumn{2}{|l|}{ Home appliances } & \multicolumn{2}{|c|}{ Home improvement } \\
\hline & & \multicolumn{2}{|l|}{ Furniture and lighting } & \multicolumn{2}{|c|}{ Electrical household appliances } & \multicolumn{2}{|c|}{$\begin{array}{l}\text { Hardware, paints and } \\
\text { glass }\end{array}$} \\
\hline \multicolumn{2}{|l|}{ Top searches } & \multicolumn{2}{|l|}{ Top searches } & \multicolumn{2}{|l|}{ Top searches } & \multicolumn{2}{|l|}{ Top searches } \\
\hline blinds & 100 & furniture & 100 & fridge & 100 & $b \& q$ & 100 \\
\hline $\mathrm{mfi}$ & 70 & ikea & 80 & hotpoint & 80 & homebase & 100 \\
\hline curtains & 60 & beds & 35 & bosch & 75 & $\mathrm{bq}$ & 70 \\
\hline curtains curtains curtains & 55 & bed & 25 & dyson & 70 & $b$ and $q$ & 40 \\
\hline bedroom & 50 & lighting & 25 & washing machine & 70 & diy & 35 \\
\hline ikea & 40 & sofa & 20 & oven & 55 & $b \& q$ & 30 \\
\hline colour & 30 & sofa sofa & 20 & cooker & 50 & kitchen & 30 \\
\hline room & 30 & table & 20 & cookers & 50 & kitchens & 30 \\
\hline decorating & 25 & chairs & 15 & dishwasher & 45 & wickes & 30 \\
\hline colours & 20 & dfs & 15 & fridge freezer & 40 & focus & 25 \\
\hline mirrors & 20 & laura ashley & 15 & hoover & 40 & paint & 20 \\
\hline wallpaper & 20 & sofas & 15 & miele & 40 & dulux & 15 \\
\hline bedroom furniture & 15 & carpets & 10 & washing machines & 40 & focus diy & 15 \\
\hline bedrooms & 15 & chair & 10 & comet & 35 & insulation & 15 \\
\hline kitchens & 15 & citizens advice & 10 & freezers & 35 & $\mathrm{bq}$ & 10 \\
\hline mosaic & 15 & habitat & 10 & zanussi & 35 & homebase uk & 10 \\
\hline plant & 15 & john lewis & 10 & microwave & 30 & tools & 10 \\
\hline plants & 15 & lights & 10 & ovens & 30 & wicks & 10 \\
\hline wardrobes & 15 & mattress & 10 & radiators & 30 & machine mart & 5 \\
\hline interior design & 10 & tables & 10 & whirlpool & 30 & screwfix & 5 \\
\hline Rising searches & & Rising searches & & Rising searches & & Rising searches & \\
\hline samsung pc studio & Breakout & homebase & $80 \%$ & casas bahia & Breakout & wilkinsons & $170 \%$ \\
\hline decoracion & $550 \%$ & $\operatorname{scs}$ & $80 \%$ & you yube & Breakout & bq & $150 \%$ \\
\hline laura ashley & $160 \%$ & furniture village & $70 \%$ & beko & $70 \%$ & screwfix & $110 \%$ \\
\hline hillarys blinds & $60 \%$ & land of leather & $70 \%$ & fridge freezer & $40 \%$ & bandq & $100 \%$ \\
\hline bedroom ideas & $40 \%$ & john lewis & $60 \%$ & & & howdens & $70 \%$ \\
\hline curtains & $40 \%$ & harveys & $50 \%$ & & & $\mathrm{~b}$ and $\mathrm{q}$ & $50 \%$ \\
\hline ikea uk & $40 \%$ & ikea uk & $50 \%$ & & & homebase uk & $40 \%$ \\
\hline & & laura ashley & $50 \%$ & & & & \\
\hline & & dfs & $40 \%$ & & & & \\
\hline & & harveys furniture & $40 \%$ & & & & \\
\hline
\end{tabular}




\begin{tabular}{|c|c|c|c|c|c|c|c|}
\hline \multirow{2}{*}{\multicolumn{2}{|c|}{$\begin{array}{l}\text { Music streams and downloads } \\
\text { Audio and video equipment and } \\
\text { recordings }\end{array}$}} & \multirow{2}{*}{\multicolumn{2}{|c|}{$\begin{array}{l}\text { Music retailers } \\
\text { Audio and video equipment and } \\
\text { recordings }\end{array}$}} & \multirow{2}{*}{\multicolumn{2}{|c|}{$\begin{array}{l}\text { Audio equipment } \\
\text { Audio and video equipment } \\
\text { and recordings }\end{array}$}} & \multirow{2}{*}{\multicolumn{2}{|c|}{$\begin{array}{l}\text { Consumer electronics } \\
\text { Audio and video equipment } \\
\text { and recordings }\end{array}$}} \\
\hline & & & & & & & \\
\hline \multicolumn{2}{|l|}{ Top searches } & \multicolumn{2}{|l|}{ Top searches } & \multicolumn{2}{|l|}{ Top searches } & \multicolumn{2}{|l|}{ Top searches } \\
\hline itunes & 100 & $\mathrm{hmv}$ & 100 & ipod & 100 & ipod & 100 \\
\hline download & 75 & cd wow & 10 & mp3 & 20 & tv & 70 \\
\hline music & 70 & hmv uk & 10 & sony & 20 & sony & 65 \\
\hline mp3 & 60 & albums & 5 & apple & 15 & Icd & 40 \\
\hline downloads & 45 & cds & 5 & ipod nano & 15 & panasonic & 35 \\
\hline free music & 40 & cdwow & 5 & ipod touch & 15 & samsung & 25 \\
\hline free downloads & 30 & hmv music & 5 & speakers & 15 & Icd tv & 20 \\
\hline music downloads & 30 & new releases & 5 & apple ipod & 10 & speakers & 20 \\
\hline free $\mathrm{mp} 3$ & 25 & records & 5 & creative & 10 & apple & 15 \\
\hline itunes download & 25 & virgin megastore & 5 & dab & 10 & ipod nano & 15 \\
\hline download music & 20 & virgin megastores & 5 & headphones & 10 & ipod touch & 15 \\
\hline music downloads free & 20 & amazon music & 0 & hifi & 10 & richer sounds & 15 \\
\hline musica & 20 & fopp & 0 & mp3 player & 10 & apple ipod & 10 \\
\hline download mp3 & 15 & htfr & 0 & richer sounds & 10 & bose & 10 \\
\hline i tunes & 15 & new albums & 0 & dab radio & 5 & creative & 10 \\
\hline musicas & 15 & new music & 0 & hi fi & 5 & currys & 10 \\
\hline midi & 10 & richard branson & 0 & i pod & 5 & headphones & 10 \\
\hline mp3 downloads & 10 & virgin music & 0 & iphone & 5 & iphone & 10 \\
\hline $\mathrm{mtv}$ & 10 & virgin store & 0 & mp3 players & 5 & mp3 player & 10 \\
\hline 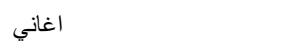 & 10 & zavvi & 0 & sennheiser & 5 & toshiba & 10 \\
\hline Rising searches & & Rising searches & & Rising searche & & Rising searche & \\
\hline baixar musicas & Breakout & zavvi & Breakout & iphone & Breakout & iphone & Breakout \\
\hline musicas & Breakout & maximo & $200 \%$ & ipod nano & Breakout & ipod nano & Breakout \\
\hline ouvir musicas & Breakout & amazon music & $70 \%$ & ipod shuffle & Breakout & ipod touch & Breakout \\
\hline escuchar musica & $5000 \%$ & $\mathrm{hmv}$ & $60 \%$ & ipod touch & Breakout & samsung & $200 \%$ \\
\hline musica & $3400 \%$ & hmv uk & $60 \%$ & mp4 & $250 \%$ & Icd tv & $180 \%$ \\
\hline itunes download & $850 \%$ & new releases & $60 \%$ & bose & $130 \%$ & currys & $130 \%$ \\
\hline free itunes & $800 \%$ & new releases music & $50 \%$ & ipod & $70 \%$ & Icd & $130 \%$ \\
\hline itunes & $300 \%$ & new albums & $40 \%$ & apple ipod & $50 \%$ & ipod & $80 \%$ \\
\hline طرب & $300 \%$ & & & headphones & $50 \%$ & tv & $60 \%$ \\
\hline i tunes & $160 \%$ & & & apple & $40 \%$ & apple & $50 \%$ \\
\hline
\end{tabular}




\begin{tabular}{|c|c|c|c|c|c|c|c|}
\hline \multirow{2}{*}{\multicolumn{2}{|c|}{$\begin{array}{l}\text { Home video } \\
\text { Audio and video equipment } \\
\text { and recordings }\end{array}$}} & \multicolumn{2}{|l|}{ Book retailers } & \multicolumn{2}{|c|}{ Personal electronics } & \multicolumn{2}{|c|}{ Consumer electronics } \\
\hline & & \multicolumn{2}{|c|}{ Books, newspapers and stationery } & \multicolumn{2}{|c|}{$\begin{array}{l}\text { Computers and } \\
\text { telecommunications }\end{array}$} & \multicolumn{2}{|c|}{$\begin{array}{l}\text { Computers and } \\
\text { telecommunications }\end{array}$} \\
\hline \multicolumn{2}{|l|}{ Top searches } & \multicolumn{2}{|l|}{ Top searches } & \multicolumn{2}{|l|}{ Top searches } & \multicolumn{2}{|l|}{ Top searches } \\
\hline tv & 100 & amazon & 100 & palm & 100 & ipod & 100 \\
\hline Icd & 60 & amazon uk & 70 & ipaq & 80 & tv & 70 \\
\hline Icd tv & 40 & books & 35 & pda & 70 & sony & 65 \\
\hline sony & 35 & waterstones & 30 & windows mobile & 65 & Icd & 40 \\
\hline panasonic & 30 & amazon books & 15 & pocket pc & 55 & panasonic & 35 \\
\hline samsung & 25 & whsmith & 10 & sync & 50 & samsung & 25 \\
\hline dvd player & 15 & abe & 5 & blackberry & 45 & Icd tv & 20 \\
\hline hdmi & 15 & abe books & 5 & gadgets & 45 & speakers & 20 \\
\hline projector & 15 & amazon books uk & 5 & activesync & 40 & apple & 15 \\
\hline toshiba & 15 & amozon & 5 & gadget & 30 & ipod nano & 15 \\
\hline tvs & 15 & blackwells & 5 & hp ipaq & 30 & ipod touch & 15 \\
\hline blu ray & 10 & book people & 5 & firebox & 25 & richer sounds & 15 \\
\hline dvd recorder & 10 & bookshop & 5 & htc & 25 & apple ipod & 10 \\
\hline hd tv & 10 & borders & 5 & treo & 25 & bose & 10 \\
\hline $\lg$ & 10 & the book people & 5 & active sync & 20 & creative & 10 \\
\hline plasma tv & 10 & waterstones books & 5 & gadget shop & 20 & currys & 10 \\
\hline samsung Icd & 10 & wh smith & 5 & ebook & 15 & headphones & 10 \\
\hline samsung tv & 10 & wh smiths & 5 & 02 iphone & 15 & iphone & 10 \\
\hline sony tv & 10 & whsmiths & 5 & smartphone & 15 & mp3 player & 10 \\
\hline televisions & 10 & isbn & 0 & $x d a$ & 15 & toshiba & 10 \\
\hline Rising searches & & Rising searches & & Rising searches & & Rising search & \\
\hline hd tv & Breakout & lea walker & Breakout & blackberry apps & Breakout & iphone & Breakout \\
\hline blu ray & $4500 \%$ & saraiva & Breakout & htc & Breakout & ipod nano & Breakout \\
\hline hdmi & $1550 \%$ & lea & $1000 \%$ & o2 iphone & Breakout & ipod touch & Breakout \\
\hline samsung Icd & $700 \%$ & imogen & $400 \%$ & blackberry & $550 \%$ & samsung & $200 \%$ \\
\hline samsung tv & $500 \%$ & play.com uk & $350 \%$ & windows mobile & $500 \%$ & Icd tv & $180 \%$ \\
\hline samsung & $250 \%$ & amzon & $110 \%$ & ebook & $140 \%$ & currys & $130 \%$ \\
\hline Icd tv & $170 \%$ & amazon uk & $80 \%$ & firebox & $90 \%$ & Icd & $130 \%$ \\
\hline Icd & $130 \%$ & amazon & $70 \%$ & sync & $70 \%$ & ipod & $80 \%$ \\
\hline $\lg$ & $90 \%$ & & & & & tv & $60 \%$ \\
\hline tvs & $90 \%$ & & & & & apple & $50 \%$ \\
\hline
\end{tabular}




\begin{tabular}{|c|c|c|c|c|c|c|c|}
\hline \multicolumn{2}{|l|}{ Mobile and wireless } & \multicolumn{2}{|l|}{ Mobile phones } & \multicolumn{2}{|l|}{ Telecommunications } & \multicolumn{2}{|c|}{$\begin{array}{l}\text { Shopping portals and } \\
\text { search engines }\end{array}$} \\
\hline $\begin{array}{l}\text { Computers and } \\
\text { telecommunications }\end{array}$ & & $\begin{array}{l}\text { Computers and } \\
\text { telecommunications }\end{array}$ & & $\begin{array}{l}\text { Computers and } \\
\text { telecommunications }\end{array}$ & & $\begin{array}{l}\text { Non-store retailing } \\
\text { firms) }\end{array}$ & (large \\
\hline Top searches & & Top searches & & Top searches & & Top searches & \\
\hline mobile & 100 & nokia & 100 & mobile & 100 & argos & 100 \\
\hline nokia & 90 & mobile & 80 & nokia & 85 & additions & 5 \\
\hline 02 & 65 & phones & 60 & bt & 65 & argos uk & 5 \\
\hline phones & 55 & sony & 50 & 02 & 65 & empire & 5 \\
\hline samsung & 45 & carphone & 45 & orange & 65 & littlewoods & 5 \\
\hline sony & 45 & samsung & 45 & phones & 50 & littlewoods direct & 5 \\
\hline vodafone & 40 & ericsson & 40 & broadband & 45 & mercado libre & 5 \\
\hline carphone & 35 & sony ericsson & 40 & samsung & 45 & woolworths & 5 \\
\hline sony ericsson & 35 & carphone warehouse & 35 & sky & 45 & additions direct & 0 \\
\hline blackberry & 30 & iphone & 35 & vodafone & 40 & argos additions & 0 \\
\hline carphone warehouse & 30 & mobile phone & 30 & carphone & 35 & argos direct & 0 \\
\hline iphone & 30 & mobile phones & 30 & iphone & 35 & argos toys & 0 \\
\hline mobile phone & 30 & ०2 & 30 & yahoo & 35 & asda direct & 0 \\
\hline mobile phones & 25 & orange & 25 & blackberry & 30 & empire direct & 0 \\
\hline orange & 25 & motorola & 20 & bt yahoo & 30 & empire stores & 0 \\
\hline motorola & 20 & vodafone & 15 & carphone warehouse & 30 & freemans & 0 \\
\hline sms & 15 & 2 & 10 & mobile phone & 30 & mercado livre & 0 \\
\hline t mobile & 15 & htc & 10 & sony ericsson & 30 & mercadolibre & 0 \\
\hline twitter & 15 & $\lg$ & 10 & iplayer & 25 & tesco direct & 0 \\
\hline virgin & 15 & phones $4 \mathrm{u}$ & 10 & mobile phones & 20 & toys $r$ us & 0 \\
\hline Rising searches & & Rising searches & & Rising searches & & Rising searches & \\
\hline claro & Breakout & htc & Breakout & iphone & Breakout & mercado libre & Breakout \\
\hline iphone & Breakout & iphone & Breakout & iplayer & Breakout & mercado livre & Breakout \\
\hline twitter & Breakout & n95 & Breakout & twitter & Breakout & mercadolibre & Breakout \\
\hline oi & $4950 \%$ & 2 & $80 \%$ & blackberry & $400 \%$ & asda direct & $4850 \%$ \\
\hline htc & $4600 \%$ & $\lg$ & $70 \%$ & skype & $350 \%$ & tesco direct & $2500 \%$ \\
\hline blackberry & $400 \%$ & carphone & $50 \%$ & bt yahoo & $250 \%$ & littlewoods direct & $900 \%$ \\
\hline $\lg$ & $70 \%$ & carphone warehouse & $50 \%$ & yahoo & $200 \%$ & argos direct & $70 \%$ \\
\hline vodafone & $60 \%$ & samsung & $50 \%$ & tomtom & $130 \%$ & empire stores & $40 \%$ \\
\hline virgin & $50 \%$ & vodafone & $50 \%$ & sky & $70 \%$ & & \\
\hline carphone warehouse & $40 \%$ & o2 & $40 \%$ & virgin & $70 \%$ & & \\
\hline
\end{tabular}




\begin{tabular}{|c|c|c|c|c|c|c|c|}
\hline \multicolumn{2}{|c|}{$\begin{array}{l}\text { Vehicle licensing and } \\
\text { registration }\end{array}$} & \multicolumn{2}{|l|}{ Automotive } & \multicolumn{2}{|c|}{ Vehicle shopping } & \multicolumn{2}{|c|}{ Vehicle brands } \\
\hline \multicolumn{2}{|l|}{ Car registrations } & \multicolumn{2}{|c|}{ Car registrations } & \multicolumn{2}{|c|}{ Car registrations } & \multicolumn{2}{|c|}{ Car registrations } \\
\hline \multicolumn{2}{|l|}{ Top searches } & \multicolumn{2}{|c|}{ Top searches } & \multicolumn{2}{|l|}{ Top searches } & \multicolumn{2}{|c|}{ Top searches } \\
\hline dvla & 100 & car & 100 & autotrader & 100 & $\mathrm{bmw}$ & 100 \\
\hline driving & 40 & autotrader & 50 & car & 55 & ford & 85 \\
\hline number plates & 20 & cars & 40 & auto & 45 & audi & 80 \\
\hline driving licence & 10 & insurance & 40 & trader & 45 & $\mathrm{vw}$ & 75 \\
\hline dvla plates & 10 & ford & 30 & auto trader & 40 & cars & 55 \\
\hline dvla tax & 10 & auto & 25 & cars & 40 & peugeot & 45 \\
\hline car registration & 5 & car insuranc & 25 & parkers & 15 & renault & 45 \\
\hline car tax & 5 & auto trader & 20 & used cars & 15 & mercedes & 40 \\
\hline driving lessons & 5 & $\mathrm{bmw}$ & 20 & autotrader uk & 10 & fiat & 35 \\
\hline driving school & 5 & dvla & 20 & ford & 10 & honda & 35 \\
\hline driving test & 5 & trader & 20 & used car & 10 & nissan & 35 \\
\hline dvla car tax & 5 & audi & 15 & audi & 5 & toyota & 35 \\
\hline $\begin{array}{l}\text { dvla number } \\
\text { plates }\end{array}$ & 5 & ebay & 15 & bmw & 5 & volvo & 35 \\
\hline number plate & 5 & honda & 15 & car dealers & 5 & porsche & 30 \\
\hline private plates & 5 & mercedes & 15 & car sales & 5 & volkswagen & 30 \\
\hline provisional & 5 & vauxhall & 15 & cars for sale & 5 & citroen & 25 \\
\hline registrations & 5 & $\mathrm{vw}$ & 15 & cars sale & 5 & mazda & 25 \\
\hline road tax & 5 & halfords & 10 & parkers guide & 5 & $\operatorname{mini}$ & 25 \\
\hline tax disc & 5 & renault & 10 & toyota & 5 & land rover & 20 \\
\hline vehicle & 5 & toyota & 10 & vauxhall & 5 & vauxhall & 20 \\
\hline \multicolumn{2}{|l|}{ Rising searches } & \multicolumn{2}{|c|}{ Rising searches } & \multicolumn{2}{|c|}{ Rising searches } & \multicolumn{2}{|c|}{ Rising searches } \\
\hline dvla address & $450 \%$ & pistonheads & $2000 \%$ & ebay motors & $600 \%$ & fiat 500 & $550 \%$ \\
\hline dvla car tax & $450 \%$ & car games & $300 \%$ & autos & $250 \%$ & chevrolet & $190 \%$ \\
\hline car tax & $300 \%$ & ebay & $200 \%$ & car giant & $110 \%$ & bugatti & $160 \%$ \\
\hline dvla tax & $300 \%$ & car tax & $180 \%$ & autotrader & $90 \%$ & what car & $70 \%$ \\
\hline tax disc & $300 \%$ & autotrader & $140 \%$ & cargiant & $80 \%$ & auto trader & $50 \%$ \\
\hline $\begin{array}{l}\text { provisional } \\
\text { licence }\end{array}$ & $190 \%$ & halfords & $60 \%$ & ebay cars & $60 \%$ & audi a4 & $40 \%$ \\
\hline vosa & $120 \%$ & trader & $60 \%$ & & & kia & $40 \%$ \\
\hline provisional & $110 \%$ & auto trader & $50 \%$ & & & parkers & $40 \%$ \\
\hline car check & $70 \%$ & auto & $40 \%$ & & & range rover & $40 \%$ \\
\hline road tax & $70 \%$ & what car & $40 \%$ & & & & \\
\hline
\end{tabular}




\begin{tabular}{|c|c|c|c|c|c|c|c|}
\hline \multicolumn{2}{|l|}{ Auto financing } & \multicolumn{2}{|l|}{ Real estate } & \multicolumn{2}{|c|}{$\begin{array}{l}\text { Home inspections and } \\
\text { appraisals }\end{array}$} & \multicolumn{2}{|l|}{ Home financing } \\
\hline Car registrations & & Property transactions & & Property transactions & & Mortgage approvals & \\
\hline Top searches & & Top searches & & Top searches & & Top searches & \\
\hline leasing & 100 & estate agents & 100 & whats my & 100 & mortgage & 100 \\
\hline lease & 80 & property & 85 & assessor & 55 & nationwide & 80 \\
\hline leasing car & 70 & rightmove & 75 & assessors & 45 & money & 45 \\
\hline finance & 60 & houses & 55 & appraisal & 35 & mortgages & 45 \\
\hline lease car & 40 & mortgage & 35 & whats car worth & 25 & money supermarket & 40 \\
\hline car finance & 30 & housing & 30 & home inspector & 15 & mortgage calculator & 35 \\
\hline black horse & 15 & right move & 30 & appraiser & 10 & moneysupermarket & 20 \\
\hline contract hire & 15 & houses for sale & 25 & assesor & 10 & northern rock & 20 \\
\hline lease cars & 15 & nationwide & 25 & energy assessor & 10 & compare & 15 \\
\hline lease hire & 15 & property for sale & 20 & home inspection & 10 & buy to let & 10 \\
\hline black horse finance & 10 & mortgages & 15 & home inspectors & 10 & car insurance & 10 \\
\hline blackhorse & 10 & flats to rent & 10 & treasurer & 10 & loans & 10 \\
\hline car credit & 10 & gumtree & 10 & assesors & 5 & mortgage rates & 10 \\
\hline car loan & 10 & halifax & 10 & assessor jobs & 5 & best mortgage & 5 \\
\hline car loans & 10 & house prices & 10 & cedae & 5 & capital gains & 5 \\
\hline contract hire leasing & 10 & houses to rent & 10 & e-vision & 5 & compare car insurance & 5 \\
\hline contract leasing & 10 & land registry & 10 & investment appraisal & 5 & morgage & 5 \\
\hline fipe & 10 & money supermarket & 10 & scottish assessors & 5 & mortgage deals & 5 \\
\hline lex & 10 & mortgage calculator & 10 & whats my angle & 5 & mortgage rate & 5 \\
\hline vehicle leasing & 10 & real & 10 & whats my speed & 5 & mortgage uk & 5 \\
\hline Rising searches & & Rising searches & & Rising searches & & Rising searches & \\
\hline consorcio & Breakout & gumtree & $3750 \%$ & assessor jobs & Breakout & compare the market & Breakout \\
\hline fipe & Breakout & money supermarket & $500 \%$ & energy assessor & Breakout & compare car insurance & $850 \%$ \\
\hline tabela fipe & Breakout & moneysupermarket & $400 \%$ & home inspector & Breakout & car insurance & $550 \%$ \\
\hline lease car deals & $400 \%$ & rightmove & $350 \%$ & whats car worth & $500 \%$ & money supermarket & $500 \%$ \\
\hline car leasing deals & $350 \%$ & right move & $250 \%$ & home inspectors & $200 \%$ & moneysupermarket & $400 \%$ \\
\hline audi leasing & $140 \%$ & nationwide & $80 \%$ & assessor & $180 \%$ & money & $350 \%$ \\
\hline lease a car & $120 \%$ & house prices & $70 \%$ & whats my & $180 \%$ & compare & $170 \%$ \\
\hline audi lease & $100 \%$ & houses to rent & $70 \%$ & home inspection & $130 \%$ & bbc mortgage & $160 \%$ \\
\hline loan calculator & $60 \%$ & swansea & $70 \%$ & assesor & $120 \%$ & nationwide & $80 \%$ \\
\hline lease bmw & $50 \%$ & savills & $50 \%$ & assessors & $120 \%$ & pret & $80 \%$ \\
\hline
\end{tabular}




\begin{tabular}{|c|c|c|c|c|c|c|c|c|c|}
\hline \multirow{2}{*}{$\begin{array}{l}\text { Travel } \\
\text { Overseas visits }\end{array}$} & \multicolumn{3}{|c|}{ Vacation destinations } & \multicolumn{2}{|l|}{$\begin{array}{l}\text { Hotels and } \\
\text { accommodation }\end{array}$} & \multicolumn{2}{|l|}{ Air travel } & \multicolumn{2}{|c|}{ Cruises and charters } \\
\hline & & Overseas visits & & Overseas visits & & Overseas visits & & Overseas visits & \\
\hline Top searches & & Top searches & & Top searches & & Top searches & & Top searches & \\
\hline hotel & 100 & holidays & 100 & hotel & 100 & flights & 100 & cruises & 100 \\
\hline flights & 70 & new york & 95 & hotels & 50 & cheap flights & 40 & ferries & 100 \\
\hline holidays & 65 & last minute & 75 & holiday & 20 & easyjet & 40 & cruise & 85 \\
\hline hotels & 50 & vegas & 75 & Iondon & 20 & airlines & 35 & ferry & 85 \\
\hline train & 40 & las vegas & 70 & edinburgh & 15 & ryanair & 35 & $\mathrm{p} \& \mathrm{o}$ & 40 \\
\hline travel & 40 & paris & 50 & cottages & 10 & british airways & 20 & thames & 20 \\
\hline holiday & 30 & virgin holidays & 45 & hilton & 10 & heathrow & 20 & ferries france & 15 \\
\hline cheap flights & 25 & orlando & 40 & holiday inn & 10 & gatwick & 15 & $p$ and $o$ & 15 \\
\hline easyjet & 25 & barbados & 35 & premier inn & 10 & virgin & 15 & p\&o ferries & 15 \\
\hline national rail & 20 & disneyland & 35 & travelodge & 10 & airport parking & 10 & royal caribbean & 15 \\
\hline ryanair & 20 & jamaica & 35 & blackpool & 5 & ba & 10 & stena & 15 \\
\hline train times & 20 & disney & 30 & cheap hotels & 5 & belfast & 10 & dover calais & 10 \\
\hline virgin & 20 & disneyland paris & 30 & dubai & 5 & bmi & 10 & ferry dover & 10 \\
\hline edinburgh & 15 & florida & 30 & holidays & 5 & easy jet & 10 & ferry france & 10 \\
\hline gatwick & 15 & lastminute & 30 & ibis & 5 & flybe & 10 & ferry to france & 10 \\
\hline heathrow & 15 & new york hotel & 30 & Iondon hotels & 5 & manchester airport & 10 & irish ferries & 10 \\
\hline thomas cook & 15 & cuba & 25 & marriott & 5 & monarch & 10 & $p \& o$ & 10 \\
\hline trains & 15 & all inclusive & 20 & travel inn & 5 & ryan air & 10 & p o ferries & 10 \\
\hline cheap holidays & 10 & caribbean & 20 & travel lodge & 5 & stansted & 5 & princess cruises & 10 \\
\hline weather & 10 & hong kong & 20 & trip advisor & 5 & virgin atlantic & 5 & stena line & 10 \\
\hline Rising searches & & Rising searches & & Rising searches & & Rising searches & & Rising searches & \\
\hline premier inn & $750 \%$ & 6 travelzoo & Breakou & trip advisor & $1100 \%$ & travel supermarket & $2050 \%$ & cruises 2010 & Breakout \\
\hline trainline & $130 \%$ & 6 travel zoo & $3750 \%$ & premier inn & $800 \%$ & skyscanner & $800 \%$ & norfolkline & $450 \%$ \\
\hline first choice & $120 \%$ & panama & $180 \%$ & tripadvisor & $750 \%$ & thomas cook & $140 \%$ & cruise deals & $250 \%$ \\
\hline national rail & $120 \%$ & 6 virgin atlantic & $120 \%$ & laterooms & $250 \%$ & jet2 & $120 \%$ & royal caribbean & $250 \%$ \\
\hline thomson & $120 \%$ & 6 queens & $80 \%$ & premier travel inn & $250 \%$ & thomson & $110 \%$ & $\mathrm{ncl}$ & $130 \%$ \\
\hline thomson holidays & $110 \%$ & 6 all inclusive & $70 \%$ & late rooms & $200 \%$ & virgin atlantic & $80 \%$ & norfolk & $120 \%$ \\
\hline thomas cook & $100 \%$ & 6 last minute deals & $70 \%$ & travelodge & $100 \%$ & baa & $70 \%$ & norfolk line & $120 \%$ \\
\hline travelodge & $100 \%$ & 6 virgin holidays & $70 \%$ & last minute & $50 \%$ & ryanair & $60 \%$ & caribbean cruises & $100 \%$ \\
\hline national express & $60 \%$ & & & harrogate & $40 \%$ & aer lingus & $50 \%$ & celebrity cruises & $80 \%$ \\
\hline ryanair & $50 \%$ & & & hotel reviews & $40 \%$ & ba & $50 \%$ & princess cruises & $80 \%$ \\
\hline
\end{tabular}

